\title{
Unique monocyte transcriptomic profiles are associated with preclinical atherosclerosis in women with systemic lupus erythematosus (SLE)
}

\section{Short title: Monocyte gene signatures in SLE and atherosclerosis}

Laurel Woodridge1,2,3, Elvira C Chocano1,2, Paul Ashford3, George Robinson2, Kirsty

Waddington1,2, Anisur Rahman2, Christine Orengo3, Elizabeth C Jury2\#, Inés Pineda Torra1\#

${ }_{1}$ Centre for Cardiometabolic and Vascular Science and 2 Centre for Rheumatology, Division of Medicine, University College of London, 5 University Street, London, WC1 E6JF, United Kingdom.

3 Institute of Structural and Molecular Biology, University College London, Gower Street, London, WC1E 6BT, UK.

\# Equal contribution

Corresponding author: Inés Pineda-Torra, E-mail: i.torra@ucl.ac.uk 
medRxiv preprint doi: https://doi.org/10.1101/2020.08.05.20169136; this version posted August 6, 2020. The copyright holder for this

preprint (which was not certified by peer review) is the author/funder, who has granted medRxiv a license to display the preprint in

It is made available under a CC-BY-NC-ND 4.0 International license

\begin{abstract}
Women with Systemic Lupus Erythematosus (SLE) show significantly increased cardiovascular risk compared to the general population. However, despite CVD being a major cause of morbidity and mortality for these women, this increased risk is not managed clinically and tools to dissect and predict their cardiovascular risk are lacking. Notably, this elevated CVD risk is not captured by traditional risk factors. To explore molecular programs underlying asymptomatic atherosclerosis in SLE we used a well-characterised cohort of CVD-free women with SLE, scanned for asymptomatic atherosclerotic plaques using non-invasive ultrasound imaging of the carotid and femoral arteries. We investigated the transcriptomic profiles of CD14+ circulating monocytes in women with SLE with or without preclinical atherosclerosis. We identified unique monocytic gene expression profiles that distinguished the presence of preclinical plaques in women with SLE. In addition, advanced bioinformatic analysis revealed functional pathways and interactions between the genes identified that could explain mechanistic differences in plaque formation. We propose that these molecular signatures could help understand why a subset of women with SLE are predisposed to develop atherosclerosis and at higher risk of developing clinical CVD. Collectively with other efforts, these molecular insights will help to better define atherosclerosis in the context of SLE which will be critical for future patient stratification and identification of anti-atherosclerotic therapies.
\end{abstract}


medRxiv preprint doi: https://doi.org/10.1101/2020.08.05.20169136; this version posted August 6, 2020. The copyright holder for this preprint (which was not certified by peer review) is the author/funder, who has granted medRxiv a license to display the preprint in It is made available under a CC-BY-NC-ND 4.0 International license .

\section{Introduction}

Systemic lupus erythematosus (SLE) is a chronic, inflammatory auto-immune disease disproportionately affecting women (incidence of 9:1, women-to-men ratio). An unpredictable course of flares and remissions and varied symptom severity reflect the heterogeneous nature of this disease. SLE pathogenesis is attributed to the production of antibodies with specificity to a range of nuclear self-antigens and activation of effector T lymphocytes, which form immune complexes that are deposited into multiple organs, further activating immune responses (Arbuckle et al., 2003; Bayry, 2016). The progressive loss of tolerance to nuclear antigens and the accumulation of immune complexes due to impaired clearance mechanisms are central features of the disease and contribute to greater clinical severity.

A major additional risk factor in SLE and a leading cause of mortality is cardiovascular disease (CVD) and accelerated atherosclerosis, with asymptomatic atherosclerotic plaques presenting prior to CVD onset (Björnådal et al., 2004; Schoenfeld et al., 2013). Atherosclerosis results from a complex process involving abnormal or dysregulated circulating lipids and exacerbated inflammation, leading to the uptake of modified lipoproteins and accumulation of immune cells within the arterial wall (Moore et al., 2013). Specifically, an early stage in this process is the recruitment of circulating monocytes to the subendothelial space, subsequently differentiating into macrophages. Due to dysregulated cholesterol efflux these cells become lipid-laden or "foamy", showing impaired migratory capacity and enhanced secretion of proinflammatory cytokines which further perpetuate an inflammatory milieu. Apoptosis and necrosis of lipidsaturated macrophages form a necrotic core which may become unstable and prone to rupture, potentially causing strokes or myocardial infarction (Moore et al., 2013). Despite a prevalence of classical CVD risk factors in SLE patients, this alone does not account for the $\sim 50 \%$ increase in CVD-risk observed (Schoenfeld et al., 2012). This is particularly evident in the striking increase in female susceptibility in this population, with a 4-fold increase in myocardial infarctions (Esdaile et al., 2001). Despite this evidence, a female-focused mechanistic model to define CVD-risk in women with autoimmunity is lacking. Traditionally, CVD has been considered to predominantly affect men, and consequently, women have been understudied, underdiagnosed and undertreated (Balder et al., 2015; Wenger, 2018). Remarkably, over the past 10 years women have been underrepresented in trials supporting FDA-approval of new cardiometabolic drugs (Khan et al., 2020).

Likely because of the lack of appropriate stratification tools to predict CVD in women with SLE, treatment with drug therapies targeting lipid metabolism in SLE, including statins, has had mixed outcomes to date (Balder et al., 2015). As a result, clear guidelines on monitoring and management of atherosclerosis-associated complications are lacking. Thus, there is an urgent need to improve SLE patient stratification based on CVD profiles to develop adequate therapeutic approaches and reduce the CVD morbidity and mortality in this high-risk population. 
medRxiv preprint doi: https://doi.org/10.1101/2020.08.05.20169136; this version posted August 6, 2020. The copyright holder for this preprint (which was not certified by peer review) is the author/funder, who has granted medRxiv a license to display the preprint in It is made available under a CC-BY-NC-ND 4.0 International license .

In this study, using non-invasive vascular ultrasound imaging to assess the presence of preclinical atherosclerotic plaques, comprehensive global gene expression profiles have been evaluated by RNA sequencing (RNA-seq) on CD14+ circulating monocytes from women with SLE. We identified monocytic transcriptomic profiles associated with the presence of preclinical plaques in women with SLE. Advanced bioinformatic analysis also revealed functional pathways and interactions between the identified differentially expressed genes that could explain the mechanisms leading to accelerated plaque formation. We propose that these molecular signatures could help understand why a subset of women with SLE are predisposed to develop atherosclerosis and are at higher risk of developing clinical CVD.

\section{Results and Discussion}

\section{Atherosclerosis in the context of SLE is associated with a reprogrammed global monocyte gene expression}

We have a well-phenotyped cohort of $\sim 100$ atherosclerotic-CVD-free women with SLE scanned for asymptomatic atherosclerotic plaques twice over the course of 5-6 years using non-invasive ultrasound imaging of the carotid and femoral arteries (Smith et al., 2016) (Fig.1A, Table S1). A subset of patients remained atherosclerotic lesion free over this period (SLE-No Plaque or SLE-NP) whereas some patients persistently showed the presence of plaques during this time (SLE-Plaque or SLE-P). Our work previously demonstrated altered responses in lipid responsive immune-cells, namely invariant natural killer T (iNKT) cells showing increased proliferation and interleukin-4 production associated with the presence of asymptomatic atherosclerosis in SLE (Smith et al., 2016). In addition, we found this altered anti-inflammatory iNKT cell phenotype resulted from the crosstalk between iNKT cells and monocytes (Smith et al., 2016). Monocytes and macrophages play a key role in atherosclerosis plaque formation (Tabas \& Lichtman, 2017) and SLE (Ma et al., 2019) pathogenesis. Thus, to further explore the monocyte molecular programs underlying asymptomatic atherosclerosis in SLE, we next investigated the transcriptomic profiles of monocytes in women with SLE with or without atherosclerosis.

RNA-seq analysis revealed significant genome wide changes in gene expression (Fig. 1B,C) with a distinctive group of genes significantly induced (75) or reduced (181) in SLE-P compared to those with no plaques (SLE-NP). KEGG/Reactome pathway analysis using Metascape identified interferon signalling (Fig.1D), cell cycle (Fig.1D, E), purinergic receptor signalling (Fig.1D,F) and cytokine-driven pathways (Fig.1D, G) to be differentially enriched (Table 1). These pathways have been implicated in SLE and atherogenesis (Flynn et al., 2019) or both. For instance, local proliferation of macrophages within the plaque has been implicated in the maintenance of macrophage plaque content, particularly in advanced lesions (Hilgendorf et al., 2013). In addition, elevated numbers of circulating monocytes have been associated with increased CVD risk (Coller, 2005) and monocytosis has been causally linked to accelerated atherosclerosis progression and impaired lesion regression (Swirski et al., 2007; Waterhouse et al., 2008). Perhaps counterintuitively, SLE-P monocytes expressed lower levels of genes implicated in 
medRxiv preprint doi: https://doi.org/10.1101/2020.08.05.20169136; this version posted August 6, 2020. The copyright holder for this preprint (which was not certified by peer review) is the author/funder, who has granted medRxiv a license to display the preprint in It is made available under a CC-BY-NC-ND 4.0 International license .

cell cycle progression, such as the transcription factor E2F2 (-2.04-fold, P=3.6E-04) (Fig.1E), typically associated with proliferative malignancies (Cobrinik, 1996; DeGregori, 2002). Interestingly, to our knowledge no reports linking this transcription factor with SLE or atherogenesis in the context of SLE exist. E2F2 was shown to modulate endothelial cell angiogenic responses through G1/S-phase gene expression and proliferation (J. Zhou et al., 2013). We previously reported that gene targets of this family of transcription factors are induced in macrophages from experimental models showing enhanced atherosclerosis (Gage et al., 2018). Further investigations will need to be conducted to assess the role of E2F2 on monocyte biology in the context of atherosclerosis formation in SLE.

Purinergic signalling complexes, including extracellular nucleotides and their receptors such as the P2 receptors (P2RY12), induced in the SLE-P monocytes (Fig.1D,F), are considered major regulatory systems that can regulate the development and course of multiple immune-mediated inflammatory diseases such as SLE (Antonioli et al., 2019). Previously, the P2X7 receptor, as part of the NLRP3 inflammasome signalling, has been implicated in the pathogenesis of SLE and other autoimmune diseases (Cao et al., 2019) as well as in atherosclerosis formation (Wallentin et al., 2009). Beyond P2X7R, the P2RY12 agonist Ticagrelor, known to attenuate platelet-leukocyte interactions (Schrottmaier et al., 2015), has been reported to reduce cardiovascular events in CVD patients, dampen vascular dysfunction and reduce atherosclerosis in experimental models of disease by inhibiting endothelial cell inflammation (Ganbaatar et al., 2018). More recently, P2RY12, better known as a microglia marker (Haage et al., 2019), was implicated in promoting vascular smooth muscle cell foam cell formation through the inhibition of autophagy (Pi et al., 2020), however its impact on monocyte function is not well defined. Additionally, an agonist for P2RY13 increases the uptake of HDL-cholesterol (HDL-C) by the liver in experimental models of atherosclerosis (Goffinet et al., 2014) and has been shown to protect against atherosclerosis through its role on the anti-atherogenic reverse cholesterol transport (Lichtenstein et al., 2015). Whether these actions are important for monocyte function in the context of preclinical atherosclerosis is unknown.

In addition to these, other pathways involved in cytokine and toll-like receptor signalling, known to be implicated in atherogenesis and autoimmune diseases (Hoeksema et al., 2012; Li et al., 2020; Ryu et al., 2019) are enriched in SLE-P monocytes (Fig.1D,G). For instance, IL13RA1, one of the subunits of the receptor for the immunomodulatory cytokine IL-13, observed at higher levels in SLE patients (Morimoto et al., 2001), as well as IL-6, which contributes to chronic inflammation and autoimmunity (Tanaka et al., 2014). Additionally, the anti-IL-6 receptor antibody Tocilizumab has proven effective in patients with rheumatoid arthritis (Nishimoto et al., 2004). Whereas, IL-1R1 signalling has been shown to induce human Th17 cell differentiation (Fleischmann et al., 2003; Sha \& Markovic-Plese, 2011). The identified gene expression profiles of monocytes associated with the presence of preclinical atherosclerosis suggest a less inflammatory status (Fig.1D,G), in support of our previous findings in iNKT cells (Smith et al., 2016). Interestingly, recent reports have revealed the existence of a subset of "foamy" macrophages engorged with lipids showing an anti-inflammatory profile within atherosclerotic plaques (see below) (Willemsen \& Winther, 2020). 
medRxiv preprint doi: https://doi.org/10.1101/2020.08.05.20169136; this version posted August 6, 2020. The copyright holder for this preprint (which was not certified by peer review) is the author/funder, who has granted medRxiv a license to display the preprint in It is made available under a CC-BY-NC-ND 4.0 International license .

To further investigate mechanisms explaining atherosclerosis plaque formation in SLE, we used the EnrichR algorithm to identify transcription factors involved in the regulation of the differentially (DE) genes in Fig. 1B,C. This analysis highlighted a potential role for RUNX1, a transcription factor implicated in hematologic malignancies (Olofsen \& Touw, 2020) but not previously related to atherosclerosis (Fig.1H, Table 2). Interestingly, a number of known RUNX1-regulated targets show reduced expression in SLE-P monocytes (Fig. 1I). One of the most differentially expressed genes between the SLE-P and SLE-NP groups in this subset is the free fatty acid receptor 2 or FFAR2/GPR43 (Kimura et al., 2020), a G-protein coupled receptor activated by short-chain fatty acids (SCFAs), mainly acetate, butyrate and propionate (Fig.1J). These SCFAs have shown immunomodulatory roles in monocytes by reducing the production of tumour necrosis factor alpha and monocyte chemotactic protein-1 while increasing the production of prostaglandin E2 (Cox et al., 2009). In addition, FFAR2 signalling has been demonstrated to inhibit nuclear translocation of NF$\mathrm{kB}$, thereby reducing the expression of inflammatory cytokines (IL-1 and IL-6) in cultured cells (Lee et al., 2013) (Ang et al., 2016).

Overall, we have identified novel pathways and genes associated with the presence of atherosclerotic plaques in women and confirmed the implication of pathways already associated with the development of atherosclerotic plaques.

\section{Interferon signatures do not distinguish the presence of atherosclerosis in women with SLE}

Attempts to stratify SLE patients according to unique molecular signatures have focused largely on the involvement of the interferon family of cytokines in the pathophysiology of the disease. Specifically, type 1 interferon (IFN- $\alpha$ and IFN- $\beta$ ) glycoproteins, with highly potent antiviral, anti-proliferative and immunoregulatory actions (Rönnblom \& Alm, 2001). Activation of IFN- $\alpha$, which shows elevated circulating levels in SLE patients (Hooks et al., 1979; Ytterberg \& Schnitzer, 1982), has long been considered to play a key role in the disease. In addition, high levels of IFN- $\alpha$ have been shown to associate with SLE disease activity (Baechler et al., 2003; Bengtsson et al., 2000; Crow, 2014; Kanayama et al., 1989; Obermoser \& Pascual, 2010). The term "IFN-signature" has traditionally been used to describe the overexpression of IFN-I-induced transcripts and evidence of IFN-I signalling (Bennett et al., 2003) in SLE patients compared to healthy controls. This is mainly because serum concentrations of IFN- $\alpha$ are difficult to be reliably measured. Instead, gene expression levels of IFN- $\alpha$ regulated genes are frequently used to monitor IFN activity in SLE to deduce an "IFN score" (El-Sherbiny et al., 2018; Figgett et al., 2019; Yao et al., 2009). However, existing reports have evidenced only about 50\% SLE patients show an activated IFN signature (Baechler et al., 2003).

Type I IFN signalling was shown to be dysregulated in symptomatic atherosclerotic plaque macrophages (Chai et al., 2018; Fernandez et al., 2019), however, two of the reported SLE interferon signatures (El-Sherbiny et al., 2018; Figgett et al., 2019) do not appear to stratify the presence of atherosclerosis in the women in our cohort (Fig.2A,B). Pathway analysis did indeed identify type I IFN signalling as one of the most enriched pathways in monocytes from the SLE-P group (Fig.1D; Table 3). Nevertheless, the IFN- 
medRxiv preprint doi: https://doi.org/10.1101/2020.08.05.20169136; this version posted August 6, 2020. The copyright holder for this preprint (which was not certified by peer review) is the author/funder, who has granted medRxiv a license to display the preprint in It is made available under a CC-BY-NC-ND 4.0 International license .

regulated differentially expressed genes identified show minimal overlap with those previously reported in (ElSherbiny et al., 2018; Figgett et al., 2019) (not shown) and, could also not distinguish the presence of atherosclerosis (Fig.2C). Strikingly, the interferon signature in SLE-P monocytes was significantly downregulated compared to SLE-NP monocytes (Fig. 2D)

A better stratification between SLE-P compared to SLE-NP was identified when we included the most significantly differentially expressed genes as shown by unsupervised hierarchical clustering (Fig.2E), and principal component analysis (Fig.2F). These findings may be relevant considering existing clinical trials of therapies targeting type I IFN signalling have shown variable efficacy in the treatment of SLE and other autoimmune diseases (Jiang et al., 2020). Elucidating a more definitive molecular signature of atherosclerosis in the context of SLE will be critical for patient stratification and identifying therapies for the treatment of atherosclerosis in SLE.

\section{Overlapping and distinct signalling pathways exist between SLE-P monocytes and atherosclerotic} plaque macrophages

Recent advances in the application of immunohistochemistry and bulk RNA-seq analysis (Chai et al., 2018) as well as the rapid progress of single-cell sequencing technologies (Fernandez et al., 2019) have now enabled more comprehensive transcriptional mapping of the cell types and their phenotypes present in atherosclerotic plaques. Specific subsets of cells can now be distinguished based on overlapping or differing transcriptomes giving novel insights regarding immune cell function and plaque composition. Such studies have highlighted the presence of subsets of pro-inflammatory, foamy antiinflammatory or resident-like macrophages (Willemsen \& Winther, 2020) in both murine and human plaques. In addition, some of these reports have shown that foamy macrophages are more antiinflammatory compared to non-foamy macrophages in human atherosclerotic plaques, as foamy macrophages express significantly less II1b and other pro-inflammatory markers (Kim et al., 2018).

We next interrogated which pathways overlap or are distinctive between the gene expression profiles of circulating monocytes in SLE-P patients in our study, and those of the symptomatic plaque macrophages reported in two independent studies (Fig.3). Only a subset of genes enriched in SLE-P monocytes overlap with genes enriched in plaque macrophages (27 gene overlap with genes from the single cell analysis and 11 gene overlap with those identified in the immunohistochemistry-based study) (Fig.3A, Table 4\&5). One of the overlapping genes S100A9, is part of the S1000A8/A9 damage-associated molecular pattern protein heterodimer shown to correlate with the severity of coronary artery disease (Cotoi et al., 2014; Kraakman et al., 2017; Peng et al., 2011). This complex is also emerging as a novel exciting therapeutic target to treat monocytosis and atherosclerosis in metabolic diseases (Kraakman et al., 2017; Xiao et al., 2020), as it is thought the increase in circulating monocytes could contribute to plaque macrophage accumulation and atherosclerosis (Cotoi et al., 2014). Of note, both genes in the complex show reduced expression in the SLE-P monocytes compared to those in SLE-NP (S100A9: -1.68-fold, $\mathrm{P}=3.8 \mathrm{E}-03$; S100A8: -1.77 -fold, $\mathrm{P}=2.4 \mathrm{E}-03$ ) perhaps reflecting the asymptomatic or preclinical stage of the disease in these SLE patients or differences in metabolic/inflammatory context. 
medRxiv preprint doi: https://doi.org/10.1101/2020.08.05.20169136; this version posted August 6, 2020. The copyright holder for this preprint (which was not certified by peer review) is the author/funder, who has granted medRxiv a license to display the preprint in It is made available under a CC-BY-NC-ND 4.0 International license .

Further Metascape analysis revealed that the limited number of common genes had a large degree of functional overlap with the carotid plaque macrophage transcriptomes as demonstrated by the light blue overlapping lines on the circos plot (Fig.3B). Subsequent analysis of these overlapping pathways (Table 6) confirmed the relevance of signalling by interleukins, including anti-inflammatory cytokines like IL-13 and IL-10, further supporting our previous reports (Smith et al., 2016) (Fig.3C). Interestingly, IL-13 has been shown to reduce the expression of CD36 receptor responsible for oxidised lipid uptake in macrophages and subsequent foam cell formation (Yakubenko et al., 2013). In addition, targeting IL-13 signal transduction pathways has been proposed to ameliorate vascular dysfunction in experimental models of lupus (Furumoto et al., 2017) and a number of therapeutics targeting IL-13 are being assessed in clinical trials against various autoimmune diseases (Mao et al., 2019). Furthermore, Toll-like receptor signalling and adaptive immune responses are enriched (Fig.3C). Collectively, these findings show a substantial overlap in the pathways relevant in circulating monocytes in SLE patients with preclinical atherosclerosis and those in symptomatic atherosclerosis plaques.

\section{Enhanced interaction network analysis identifies pathways involved in the adaptive immune system}

We next aimed to understand the pathways associated with atherosclerosis in SLE based on known protein-protein interactions (PPI). As a seed list, we selected genes differentially expressed between SLE-P and SLE-NP at a stringent significance threshold of $p<0.001$ (Table 7) and visualised how these mapped onto the STRINGdb PPI-network using Network Analyst (Fig. 4A) and Reactome (Fig. 4D). Within the protein network, smaller clusters of densely connected regions, known as modules, reflect functional associations between biological processes of the proteins characterised. The initial PPI-network interacting with the seed list predicted 311 nodes (proteins) and 331 edges (interactions) (24 genes were excluded due to not being present in STRINGdb PPI-network reference database at the inclusion threshold). This analysis identified a number of relevant nodes including ISG15, a well-known IFNregulated gene, FLT3 (an oncogenic receptor tyrosine kinase implicated in hematological disorders) (Voisset et al., 2020) and EIF4B, the translation eukaryotic initiation factor involved in the mTOR pathway and translation of interferon-regulated genes (Joshi et al., 2010).

An enhanced PPI network analysis complements differential expression analyses by extending the original (seed) gene lists to include interacting protein neighbours within complexes or modules within the PPI-network that may be associated with a particular biological function (Ghiassian et al., 2015). In order to further identify in silico relevant functional pathways based on reported and predicted interactions iteratively added to the subnetwork, we next conducted an enhanced network analysis using the differentially expressed genes in SLE-P versus SLE-NP groups (Fig. 1B,C) as the seed set using the DIAMOnD algorithm (Ghiassian et al., 2015) (Fig. 4B). This curated a new gene list through the addition of proteins that are likely to be interacting with each seed gene at a high confidence level. As a result, a greater number of nodes $(n=1407)$ and edges $(n=3406)$ were predicted on the enhanced gene list (85 
medRxiv preprint doi: https://doi.org/10.1101/2020.08.05.20169136; this version posted August 6, 2020. The copyright holder for this

preprint (which was not certified by peer review) is the author/funder, who has granted medRxiv a license to display the preprint in It is made available under a CC-BY-NC-ND 4.0 International license.

genes were excluded due to not being present in STRINGdb PPI-network reference database at an inclusion threshold of $>0.8$ confidence), visualised in Figure $4 \mathrm{~B}$.

Pathway enrichment analyses on the extended gene list $(n=268)$ revealed, in addition to other pathways observed in the seed list (Fig. 1D), involvement of the adaptive immune system and T-cell receptor signalling (Fig. 4C,E; Table 8). Interestingly, recent studies identified T-cells as one of the dominant immune cell subsets in symptomatic human atherosclerotic plaques and described the transcriptional dysregulation in these cells (Fernandez et al., 2019). Our ongoing studies in a different cohort of juvenile onset-SLE (JSLE) patients has confirmed T-cells in JSLE patients show distinct global gene expression profiles, enriched in genes associated with apoptosis, T-cell activation and interferon signalling (Robinson et al., 2019). However, given known sex-specific differences in immune-cells (Márquez et al., 2020), it remains unknown whether the molecular identities of immune-cell subsets in male atherosclerotic plaques (Fernandez et al., 2019) are also relevant in women.

Transcription factor analysis with EnrichR revealed a significant regulator of the expanded gene set is IRF8 (Fig. 4F; Table 9). This transcription factor is required for the development and maturation of myeloid cells (monocytes, macrophages and dendritic cells), has shown anti-microbial functions and is implicated in cell activation in response to pro-inflammatory stimuli, including IFN (Jefferies, 2019; Salem et al., 2020). Notably, our work and that of others has implicated IRF8 in atherosclerosis plaque progression (Clément et al., 2018; Döring et al., 2012; Louie et al., 2019) with pro- or anti-atherogenic actions depending on the myeloid compartment it acts on or is signalled from. In addition, IRF8 variants have been associated with circulating monocyte counts (Crosslin et al., 2013), known to be associated with increased CVD risk (Coller, 2005) and other IRF variants have been linked to the presence of atherosclerotic plaques in lupus patients (Leonard et al., 2013).

Collectively, these molecular insights may contribute to guide future therapies to treat atherosclerosis in patients with SLE. 
medRxiv preprint doi: https://doi.org/10.1101/2020.08.05.20169136; this version posted August 6, 2020. The copyright holder for this preprint (which was not certified by peer review) is the author/funder, who has granted medRxiv a license to display the preprint in It is made available under a CC-BY-NC-ND 4.0 International license .

\section{Materials \& Methods}

\section{Patient cohort}

Peripheral blood samples were collected from adult SLE $(n=24)$ patients meeting the American College of Rheumatology (ACR) classification for SLE (Hochberg, 1997) or the Systemic Lupus International Collaborating Clinics (SLICC) criteria (Petri et al., 2012), attending a young adult rheumatology clinic at University College London Hospital (UCLH) and who had no previous history of CVD. Written informed consent was obtained and all patient identifiable data was removed; subsequent patient information was anonymised in accordance with relevant data protection legislation, including the EU General Data Protection Regulation (https://www.eugdpr.org/) and UK Data Protection Bill, 2018. This study was approved by the London - City \& East Research Ethics Committee of the NHS 15-LO-2065.

\section{Vascular ultrasound scans}

Carotid and femoral ultrasound scans were conducted to assess the presence of atherosclerotic plaques. Detailed patient characteristics and information regarding scanning can be found in Smith et al., (2016). Briefly, vascular ultrasound scans of the common carotid artery, carotid bulb, carotid bifurcation, common femoral artery and femoral bifurcation were performed bilaterally using the Philips IU22 ultrasound computer and the L9-3 MHz probe. IMT measurements were performed using QLAB Advanced Quantification Software ${ }^{\circledR}$ version 7.1 (Philips Ultrasound, Bothell, USA) twice within the course of 5 years. Plaque was defined as "a focal thickening $>1.2 \mathrm{~mm}$ that encroaches into the arterial lumen as measured from the media-adventitia interface to the lumen interface" (Griffin et al., 2002). Patients who had at least one region fulfilling this description were included in the group with plaque (SLE-P). Patients were split into groups: with plaque reported in at least one region in both scans (SLE-P, $n=15$ ) and those remaining plaque-free after the second scan (SLE-NP, $n=9$ ). Peripheral blood samples (serum) were collected at the time of the second scan. SLE disease activity was determined by the British Isles Lupus Assessment Group (BILAG) Index. Clinical, demographic, serological, therapy, and disease activity characteristics for SLE-P and SLE-NP patients are shown in Table S1.

\section{RNA extraction, RNA sequencing and differential gene expression analysis}

CD14+ monocytes were isolated from peripheral blood mononuclear cells (PBMCs) by FACS-sorting. PBMCs were washed in MACS buffer (1X PBS (Sigma), 2\% FBS (Labtech) and 1mM EDTA (Sigma)) and stained with Zombie NIR ${ }^{\text {TM }}$ Fixable Viability Kit (Biolegend) in PBS followed by staining for 30 minutes with appropriate flurochrome-labelled antibodies (Biolegend), in MACS buffer. Samples were sorted in MACS buffer using BD FACSAria flow cytometry cell sorter into collection media (1xPBS, 20\% FBS). Total RNA from was extracted with TRIzol Reagent (Invitrogen). Sample concentration and purity was determined using a NanoDropTM 1000 Spectrophotometer. RNA integrity was confirmed using Agilent's 2200 Tapestation. UCL Genomics (London, UK) performed library preparation and sequencing. 
medRxiv preprint doi: https://doi.org/10.1101/2020.08.05.20169136; this version posted August 6, 2020. The copyright holder for this preprint (which was not certified by peer review) is the author/funder, who has granted medRxiv a license to display the preprint in It is made available under a CC-BY-NC-ND 4.0 International license .

Sequencing: Libraries multiplexed in the same run were pooled in equimolar quantities, calculated from Qubit and Bioanalyser fragment analysis. Samples were sequenced on the NextSeq 500 instrument (Illumina, San Diego, US) using with 43bp paired end run with an 8bp UMI read.

Sequencing data and differential gene expression analysis: Sequencing data were demultiplexed and converted to fastq files using Illumina's bcl2fastq Conversion Software. Samples were grouped by plaque status. To establish differences in gene expression between groups, sequence reads were aligned using STAR to the human hg38 reference genome. Gene count abundance was quantified using Partek E/M Annotation Model with default settings in Partek's RNA Flow software. Differential expression analysis was performed using DESeq2-3.5 in RNA Flow, via Wald hypothesis testing and parametric fit typing and using the Benjamin-Hochberg method for multiple testing correction (see Robinson et al., 2019). IFN signature gene lists were obtained from published reports (IFN-GSEA (Panwar et al., 2020), IFN-Vital (El-Sherbiny et al., 2018). Publicly available differential gene expression datasets from atherosclerotic plaque macrophages were also obtained (Chai et al., 2018; Fernandez et al., 2019).

Data visualisation: Differential gene expression lists were shown as a volcano plots using VolcaNoseR [https://huygens.science.uva.n//VolcaNoseR/] according to differential gene expression inclusion criteria $(p<0.01, F C+/-1.5)$. Heatmaps depicting normalised gene counts for gene sets of interests were created using Partek RNA Flow or ClustVis [https://biit.cs.ut.ee/clustvis/] (Metsalu \& Vilo, 2015) using correlation or Euclidian distance and average linkage for hierarchical clustering. Principle component analyses were conducted using normalised gene counts with ClustVis, using a linear transformation to interpret multivariate data into components, with components reporting the greatest amount of variance explained first. Unit variance scaling was applied to the rows and singular value decomposition with imputation was used to calculate the principal components. Venn diagrams were generated with BioVenn [https://www.biovenn.nl/index.php] (Hulsen et al., 2008).

\section{Pathway and transcription factor enrichment analysis of differential gene expression}

Pathway enrichment analysis was performed using the web-based portal Metascape [https://metascape.org/] (Y. Zhou et al., 2019) on the DEG lists using inclusion threshold (FC $<-1.5$ or $>+1.5, p<0.01$ ). Pathways were considered enriched according to a significance threshold 0 p $<0.01$, minimum overlap of 3 genes, and minimum enrichment score of 1.5 from KEGG, Reactome Gene Sets, Canonical pathways and Corum structural complex repositories. Transcription factor enrichment was performed using EnrichR [https://amp.pharm.mssm.edu/Enrichr/] (Kuleshov et al., 2016); ChEA and ENCODE repositories were used as reference. Multiple list enrichment (Metascape) was used to compare pathways enriched across multiple datasets. And common pathways and conserved genes were presented as a circos plot.

\section{Protein-protein Interaction (PPI) network analysis using DIAMOnD}


medRxiv preprint doi: https://doi.org/10.1101/2020.08.05.20169136; this version posted August 6, 2020. The copyright holder for this preprint (which was not certified by peer review) is the author/funder, who has granted medRxiv a license to display the preprint in It is made available under a CC-BY-NC-ND 4.0 International license .

STRING database (STRINGdb): Human protein interaction data was sourced from STRINGdb (version 11.0) (Szklarczyk et al., 2018), which utilises a confidence score scheme indicating the estimated likelihood a given interaction is biologically plausible. This includes direct (or physical) interactions and functional associations and combines experimental protein interaction data as well as prediction of potential interactors using co-expression analyses, automated text-mining and inclusion of gene orthology annotation data. Here, a filter was applied to exclude interactions with a score $<800$ to reduce the likelihood of including false positives and filter low-scoring edges that tend to be attributable to noise. The human protein network was constrained by this parameter to include 14712 nodes (proteins) and 728090 edges (interactions); edges were unweighted and undirected.

DIAMOnD gene set expansion: To explore disease associated genes by considering the neighbourhood of seed genes within the PPI network, the diffusion algorithm DIAMOnD (Ghiassian et al., 2015) was applied to a subset of genes differentially expressed between SLE-P and SLE-NP at a stringent threshold of $p<0.001$ ( $n=66$ genes, with 68 UniProt reviewed annotations, 12 seeds were excluded, DIAMOnD considers connectivity patterns associated with the disease genes based on a "connectivity significance" scoring scheme, that captures distantly connected proteins, obtained from STRINGdb). Any seed gene not present in the PPI-network (STRINGdb) at a confidence score of greater than 0.8 was excluded from the analysis. The confidence score indicates the likelihood a given protein is connected with another in the network, and whether this connection is biologically plausible. The high inclusion threshold used serves as a noise filter between two proteins. From the seed list, known disease genes were considered, then nodes from highly connected neighbours within a disease module were iteratively added. The combination of known disease genes and genes identified using DIAMOnD formed the disease module. An additional 200 genes were iteratively added forming the DIAMOnD-extended list.

DIAMOnD expansion enrichment and network visualisation: Pathway enrichment (Metascape) and transcription factor regulation (EnrichR) analysis were repeated on the DIAMOnD-expanded gene set as above. ReacFoam plots of pathway enrichment [https://reactome.org/reacfoam/] (Jassal et al., 2020) were obtained using Reactome pathway browser [https://reactome.org/PathwayBrowser/] to visualise pathways from Reactome ontology. Network Analyst [https://www.networkanalyst.ca] (G. Zhou et al., 2019) was used to visualise gene expression data within the context of a "generic" PPI-network. 
medRxiv preprint doi: https://doi.org/10.1101/2020.08.05.20169136; this version posted August 6, 2020. The copyright holder for this preprint (which was not certified by peer review) is the author/funder, who has granted medRxiv a license to display the preprint in It is made available under a CC-BY-NC-ND 4.0 International license.

\section{Acknowledgments:}

This work was supported by BBSRC London Interdisciplinary Biosciences PhD consortium (LIDo) to L.W., BRC-NIHR-Research Project-BRC531/III/IPT/101350 to I.P.-T. \& E.C.J., British Heart Foundation PhD studentship (FS/13/59/30649) to K.E.W., Lupus UK, The Rosetrees Trust (M409) and Multiple Sclerosis Society Project grant (076) to E.C.J. and Rosetrees Trust grant to to A.R.

\section{Author Contributions}

I.P.-T. and E.C.J designed experiments, E.C. performed cell isolation and RNA extractions. L.W performed most data analysis, visualisations and prepared first draft of figures. G.R., K.E.W, contributed with data analysis and figures, I.P.T performed initial RNA-seq bioinformatic analysis. P.A. contributed to network analysis. A.R. performed patient recruitment and assessment; L.W., C.O., E.C.J. and I.P.-T., interpreted the data, and wrote the manuscript. IPT and ECJ conceived the study, secured the funding and supervised all aspects of the work.

Competing interests: The authors declare that they have no competing interests. 
medRxiv preprint doi: https://doi.org/10.1101/2020.08.05.20169136; this version posted August 6, 2020. The copyright holder for this preprint (which was not certified by peer review) is the author/funder, who has granted medRxiv a license to display the preprint in

It is made available under a CC-BY-NC-ND 4.0 International license.

\section{References}

Ang, Z., Er, J. Z., Tan, N. S., Lu, J., Liou, Y. C., Grosse, J., \& Ding, J. L. (2016). Human and mouse monocytes display distinct signalling and cytokine profiles upon stimulation with FFAR2/FFAR3 short-chain fatty acid receptor agonists. Scientific Reports, 6(1), 1-15. https://doi.org/10.1038/srep34145

Antonioli, L., Blandizzi, C., Pacher, P., \& Haskó, G. (2019). The purinergic system as a pharmacological target for the treatment of immune-mediated inflammatory diseases. Pharmacological Reviews, 71(3), 345-382. https://doi.org/10.1124/pr.117.014878

Arbuckle, M. R., Mcclain, M. T., Rubertone, M. V, Scofield, R. H., Dennis, G. J., James, J. A., \& Harley, J. B. (2003). The new england journal of medicine $n$ engl $j$ med 349;16 www (Vol. 16). www.nejm.org

Baechler, E. C., Batliwalla, F. M., Karypis, G., Gaffney, P. M., Ortmann, W. A., Espe, K. J., Shark, K. B., Grande, W. J., Hughes, K. M., Kapur, V., Gregersen, P. K., \& Behrens, T. W. (2003). Interferoninducible gene expression signature in peripheral blood cells of patients with severe lupus. Proceedings of the National Academy of Sciences of the United States of America, 100(5), 2610 2615. https://doi.org/10.1073/pnas.0337679100

Balder, J. W., Scholtens, S., Vries, J. K. de, Schie, L. M. van, Boekholdt, S. M., Hovingh, G. K., Kamphuisen, P. W., \& Kuivenhoven, J. A. (2015). Adherence to guidelines to prevent cardiovascular diseases: The LifeLines cohort study. The Netherlands Journal of Medicine, 73(7), 316-323.

Bayry, J. (2016). Lupus pathogenesis: Role of IgE autoantibodies. In Cell Research (Vol. 26, Issue 3, pp. 271-272). Nature Publishing Group. https://doi.org/10.1038/cr.2016.12

Bengtsson, A. A., Sturfelt, G., Truedsson, L., Blomberg, J., Alm, G., Vallin, H., \& Rönnblom, L. (2000). Activation of type I interferon system in systemic lupus erythematosus correlates with disease activity but not with antiretroviral antibodies. Lupus, 9(9), 664-671. https://doi.org/10.1191/096120300674499064

Bennett, L., Palucka, A. K., Arce, E., Cantrell, V., Borvak, J., Banchereau, J., \& Pascual, V. (2003). Interferon and granulopoiesis signatures in systemic lupus erythematosus blood. Journal of Experimental Medicine, 197(6), 711-723. https://doi.org/10.1084/jem.20021553

Björnådal, L., Yin, L., Granath, F., Klareskog, L., \& Ekbom, A. (2004). Cardiovascular disease a hazard despite improved prognosis in patients with systemic lupus erythematosus: results from a Swedish population based study 1964-95. The Journal of Rheumatology, 31(4).

Cao, F., Hu, L. Q., Yao, S. R., Hu, Y., Wang, D. G., Fan, Y. G., Pan, G. X., Tao, S. S., Zhang, Q., Pan, H. F., \& Wu, G. C. (2019). P2X7 receptor: A potential therapeutic target for autoimmune diseases. In Autoimmunity Reviews (Vol. 18, Issue 8, pp. 767-777). Elsevier B.V. https://doi.org/10.1016/j.autrev.2019.06.009

Chai, J. T., Ruparelia, N., Goel, A., Kyriakou, T., Biasiolli, L., Edgar, L., Handa, A., Farrall, M., Watkins, H., \& Choudhury, R. P. (2018). Differential Gene Expression in Macrophages From Human Atherosclerotic Plaques Shows Convergence on Pathways Implicated by Genome-Wide Association Study Risk Variants. Arteriosclerosis, Thrombosis, and Vascular Biology, 38(11), 27182730. https://doi.org/10.1161/ATVBAHA.118.311209

Clément, M., Haddad, Y., Raffort, J., Lareyre, F., Newland, S. A., Master, L., Harrison, J., OzsvarKozma, M., Bruneval, P., Binder, C. J., Taleb, S., \& Mallat, Z. (2018). Deletion of IRF8 (Interferon Regulatory Factor 8)-Dependent Dendritic Cells Abrogates Proatherogenic Adaptive Immunity. Circulation Research, 122(6), 813-820. https://doi.org/10.1161/CIRCRESAHA.118.312713

Cobrinik, D. (1996). Regulatory interactions among E2Fs and cell cycle control proteins. In Current Topics in Microbiology and Immunology (Vol. 208, pp. 31-61). Springer Verlag. https://doi.org/10.1007/978-3-642-79910-5_2

Coller, B. S. (2005). Leukocytosis and ischemic vascular disease morbidity and mortality: Is it time to intervene? In Arteriosclerosis, Thrombosis, and Vascular Biology (Vol. 25, Issue 4, pp. 658-670). Lippincott Williams \& Wilkins. https://doi.org/10.1161/01.ATV.0000156877.94472.a5

Cotoi, O. S., Dunér, P., Ko, N., Hedblad, B., Nilsson, J., Björkbacka, H., \& Schiopu, A. (2014). Plasma S100A8/A9 correlates with blood neutrophil counts, traditional risk factors, and cardiovascular disease in middle-aged healthy individuals. Arteriosclerosis, Thrombosis, and Vascular Biology, 34(1), 202-210. https://doi.org/10.1161/ATVBAHA.113.302432

Cox, M. A., Jackson, J., Stanton, M., Rojas-Triana, A., Bober, L., Laverty, M., Yang, X., Zhu, F., Liu, J., 
medRxiv preprint doi: https://doi.org/10.1101/2020.08.05.20169136; this version posted August 6, 2020. The copyright holder for this preprint (which was not certified by peer review) is the author/funder, who has granted medRxiv a license to display the preprint in perpetuity.

It is made available under a CC-BY-NC-ND 4.0 International license .

Wang, S., Monsma, F., Vassileva, G., Maguire, M., Gustafson, E., Bayne, M., Chou, C.-C., Lundell, D., \& Jenh, C.-H. (2009). Short-chain fatty acids act as antiinflammatory mediatorsby regulating prostaglandin E2 and cytokines. World Journal of Gastroenterology, 15(44), 5549. https://doi.org/10.3748/wjg.15.5549

Crosslin, D. R., McDavid, A., Weston, N., Zheng, X., Hart, E., de Andrade, M., Kullo, I. J., McCarty, C. A., Doheny, K. F., Pugh, E., Kho, A., Geoffrey Hayes, M., Ritchie, M. D., Saip, A., Crawford, D. C., Crane, P. K., Newton, K., Carrell, D. S., Gallego, C. J., ... Lumley, T. (2013). Genetic variation associated with circulating monocyte count in the eMERGE Network. The Electronic Medical Records and Genomics (EMERGE) Network Human Molecular Genetics, 38(10), 2119-2127. https://doi.org/10.1093/hmg/ddt010

Crow, M. K. (2014). Type I Interferon in the Pathogenesis of Lupus. The Journal of Immunology, 192(12), 5459-5468. https://doi.org/10.4049/jimmunol.1002795

DeGregori, J. (2002). The genetics of the E2F family of transcription factors: Shared functions and unique roles. In Biochimica et Biophysica Acta - Reviews on Cancer (Vol. 1602, Issue 2, pp. 131150). Biochim Biophys Acta. https://doi.org/10.1016/S0304-419X(02)00051-3

Döring, Y., Soehnlein, O., Drechsler, M., Shagdarsuren, E., Chaudhari, S. M., Meiler, S., Hartwig, H., Hristov, M., Koenen, R. R., Hieronymus, T., Zenke, M., Weber, C., \& Zernecke, A. (2012). Hematopoietic interferon regulatory factor 8-deficiency accelerates atherosclerosis in mice. Arteriosclerosis, Thrombosis, and Vascular Biology, 32(7), 1613-1623. https://doi.org/10.1161/ATVBAHA.111.236539

El-Sherbiny, Y. M., Psarras, A., Yusof, M. Y. M., Hensor, E. M. A., Tooze, R., Doody, G., Mohamed, A. A. A., McGonagle, D., Wittmann, M., Emery, P., \& Vital, E. M. (2018). A novel two-score system for interferon status segregates autoimmune diseases and correlates with clinical features. Scientific Reports, 8(1), 1-11. https://doi.org/10.1038/s41598-018-24198-1

Esdaile, J. M., Abrahamowicz, M., Grodzicky, T., Li, Y., Panaritis, C., Berger, R. Du, Côté, R., Grover, S. A., Fortin, P. R., Clarke, A. E., \& Senécal, J. (2001). Traditional Framingham risk factors fail to fully account for accelerated atherosclerosis in systemic lupus erythematosus. Arthritis \& Rheumatism, 44(10), 2331-2337. https://doi.org/10.1002/1529-0131(200110)44:10<2331::AIDART395>3.0.CO;2-I

Fernandez, D. M., Rahman, A. H., Fernandez, N. F., Chudnovskiy, A., Amir, E. ad D., Amadori, L., Khan, N. S., Wong, C. K., Shamailova, R., Hill, C. A., Wang, Z., Remark, R., Li, J. R., Pina, C., Faries, C., Awad, A. J., Moss, N., Bjorkegren, J. L. M., Kim-Schulze, S., ... Giannarelli, C. (2019). Single-cell immune landscape of human atherosclerotic plaques. Nature Medicine, 25(10), 1576-1588. https://doi.org/10.1038/s41591-019-0590-4

Figgett, W. A., Monaghan, K., Ng, M., Alhamdoosh, M., Maraskovsky, E., Wilson, N. J., Hoi, A. Y., Morand, E. F., \& Mackay, F. (2019). Machine learning applied to whole-blood RNA-sequencing data uncovers distinct subsets of patients with systemic lupus erythematosus. Clinical \& Translational Immunology, 8(12). https://doi.org/10.1002/cti2.1093

Fleischmann, R. M., Schechtman, J., Bennett, R., Handel, M. L., Burmester, G. R., Tesser, J., Modafferi, D., Poulakos, J., \& Sun, G. (2003). Anakinra, a recombinant human interleukin-1 receptor antagonist (r-metHulL-1ra), in patients with rheumatoid arthritis: A large, international, multicenter, placebo-controlled trial. Arthritis and Rheumatism, 48(4), 927-934. https://doi.org/10.1002/art.10870

Flynn, M. C., Pernes, G., Lee, M. K. S., Nagareddy, P. R., \& Murphy, A. J. (2019). Monocytes, macrophages, and metabolic disease in atherosclerosis. In Frontiers in Pharmacology (Vol. 10, Issue JUN, p. 666). Frontiers Media S.A. https://doi.org/10.3389/fphar.2019.00666

Furumoto, Y., Smith, C. K., Blanco, L., Zhao, W., Brooks, S. R., Thacker, S. G., Zarzour, A., Sciumè, G., Tsai, W. L., Trier, A. M., Nunez, L., Mast, L., Hoffmann, V., Remaley, A. T., O’Shea, J. J., Kaplan, M. J., \& Gadina, M. (2017). Tofacitinib Ameliorates Murine Lupus and Its Associated Vascular Dysfunction. Arthritis and Rheumatology, 69(1), 148-160. https://doi.org/10.1002/art.39818

Gage, M. C., Bécares, N., Louie, R., Waddington, K. E., Zhang, Y., Tittanegro, T. H., RodríguezLorenzo, S., Jathanna, A., Pourcet, B., Pello, O. M., De la Rosa, J. V., Castrillo, A., \& Pineda-Torra, I. (2018). Disrupting Ixra phosphorylation promotes foxm1 expression and modulates atherosclerosis by inducing macrophage proliferation. Proceedings of the National Academy of Sciences of the United States of America, 115(28), E6556-E6565. https://doi.org/10.1073/pnas.1721245115

Ganbaatar, B., Fukuda, D., Salim, H. M., Nishimoto, S., Tanaka, K., Higashikuni, Y., Hirata, Y., Yagi, S., Soeki, T., \& Sata, M. (2018). Ticagrelor, a P2Y12 antagonist, attenuates vascular dysfunction and 
medRxiv preprint doi: https://doi.org/10.1101/2020.08.05.20169136; this version posted August 6, 2020. The copyright holder for this preprint (which was not certified by peer review) is the author/funder, who has granted medRxiv a license to display the preprint in perpetuity.

It is made available under a CC-BY-NC-ND 4.0 International license .

inhibits atherogenesis in apolipoprotein-E-deficient mice. Atherosclerosis, 275, 124-132.

https://doi.org/10.1016/j.atherosclerosis.2018.05.053

Ghiassian, S. D., Menche, J., \& Barabási, A.-L. (2015). A DIseAse MOdule Detection (DIAMOnD)

Algorithm Derived from a Systematic Analysis of Connectivity Patterns of Disease Proteins in the Human Interactome. PLOS Computational Biology, 11(4), e1004120.

https://doi.org/10.1371/journal.pcbi.1004120

Goffinet, M., Tardy, C., Boubekeur, N., Cholez, G., Bluteau, A., Oniciu, D. C., Lalwani, N. D., Dasseux, J.-L. H., Barbaras, R., \& Baron, R. (2014). P2Y13 Receptor Regulates HDL Metabolism and Atherosclerosis In Vivo. PLoS ONE, 9(4), e95807. https://doi.org/10.1371/journal.pone.0095807

Griffin, M., Nicolaides, A. N., Belcaro, G., \& Shah, E. (2002). Cardiovascular risk assessment using ultrasound: the value of arterial wall changes including the presence, severity and character of plaques. Pathophysiology of Haemostasis and Thrombosis, 32(5-6), 367-370. https://doi.org/10.1159/000073602

Haage, V., Semtner, M., Vidal, R. O., Hernandez, D. P., Pong, W. W., Chen, Z., Hambardzumyan, D., Magrini, V., Ly, A., Walker, J., Mardis, E., Mertins, P., Sauer, S., Kettenmann, H., \& Gutmann, D. H. (2019). Comprehensive gene expression meta-analysis identifies signature genes that distinguish microglia from peripheral monocytes/macrophages in health and glioma. Acta Neuropathologica Communications, 7(1), 20. https://doi.org/10.1186/s40478-019-0665-y

Hilgendorf, I., Weber, G. F., Theurl, I., Iwamoto, Y., Figueiredo, J.-L., Gorbatov, R., Sukhova, G. K., S Gerhardt, L. M., Smyth, D., J Zavitz, C. C., Shikatani, E. A., Parsons, M., van Rooijen, N., Lin, H. Y., Husain, M., Libby, P., Nahrendorf, M., Weissleder, R., Robbins, C. S., \& Swirski, F. K. (2013). Local proliferation dominates lesional macrophage accumulation in atherosclerosis. Nature Medicine. https://doi.org/10.1038/nm.3258

Hochberg, M. C. (1997). Updating the American College of Rheumatology revised criteria for the classification of systemic lupus erythematosus. In Arthritis and rheumatism (Vol. 40, Issue 9, p. 1725). John Wiley \& Sons, Ltd. https://doi.org/10.1002/art.1780400928

Hoeksema, M. A., Stöger, J. L., \& De Winther, M. P. J. (2012). Molecular pathways regulating macrophage polarization: Implications for atherosclerosis. Current Atherosclerosis Reports, 14(3), 254-263. https://doi.org/10.1007/s11883-012-0240-5

Hooks, J. J., Moutsopoulos, H. M., Geis, S. A., Stahl, N. I., Decker, J. L., \& Notkins, A. L. (1979). Immune Interferon in the Circulation of Patients with Autoimmune Disease. New England Journal of Medicine, 301(1), 5-8. https://doi.org/10.1056/NEJM197907053010102

Hulsen, T., de Vlieg, J., \& Alkema, W. (2008). BioVenn - A web application for the comparison and visualization of biological lists using area-proportional Venn diagrams. BMC Genomics, 9(1), 488. https://doi.org/10.1186/1471-2164-9-488

Jassal, B., Matthews, L., Viteri, G., Gong, C., Lorente, P., Fabregat, A., Sidiropoulos, K., Cook, J., Gillespie, M., Haw, R., Loney, F., May, B., Milacic, M., Rothfels, K., Sevilla, C., Shamovsky, V., Shorser, S., Varusai, T., Weiser, J., ... D'eustachio, P. (2020). The reactome pathway knowledgebase. Nucleic Acids Research, 48. https://doi.org/10.1093/nar/gkz1031

Jefferies, C. A. (2019). Regulating IRFs in IFN driven disease. In Frontiers in Immunology (Vol. 10, Issue MAR, p. 325). Frontiers Media S.A. https://doi.org/10.3389/fimmu.2019.00325

Jiang, J., Zhao, M., Chang, C., Wu, H., \& Lu, Q. (2020). Type I Interferons in the Pathogenesis and Treatment of Autoimmune Diseases. In Clinical Reviews in Allergy and Immunology (pp. 1-25). Springer. https://doi.org/10.1007/s12016-020-08798-2

Joshi, S., Kaur, S., Kroczynska, B., \& Platanias, L. C. (2010). Mechanisms of mRNA translation of interferon stimulated genes. In Cytokine (Vol. 52, Issues 1-2, pp. 123-127). Academic Press. https://doi.org/10.1016/j.cyto.2010.03.019

Kanayama, Y., Kim, T., Inariba, H., Negoro, N., Okamura, M., Takeda, T., \& Inoue, T. (1989). Possible involvement of interferon alfa in the pathogenesis of fever in systemic lupus erythematosus. Annals of the Rheumatic Diseases, 48(10), 861-863. https://doi.org/10.1136/ard.48.10.861

Khan, M. S., Shahid, I., Siddiqi, T. J., Khan, S. U., Warraich, H. J., Greene, S. J., Butler, J., \& Michos, E. D. (2020). Ten-Year Trends in Enrollment of Women and Minorities in Pivotal Trials Supporting Recent US Food and Drug Administration Approval of Novel Cardiometabolic Drugs. Journal of the American Heart Association, 9(11), e015594. https://doi.org/10.1161/JAHA.119.015594

Kim, K., Shim, D., Lee, J. S., Zaitsev, K., Williams, J. W., Kim, K.-W., Jang, M.-Y., Seok Jang, H., Yun, T. J., Lee, S. H., Yoon, W. K., Prat, A., Seidah, N. G., Choi, J., Lee, S.-P., Yoon, S.-H., Nam, J. W., Seong, J. K., Oh, G. T., ... Choi, J.-H. (2018). Transcriptome Analysis Reveals Nonfoamy Rather Than Foamy Plaque Macrophages Are Proinflammatory in Atherosclerotic Murine Models. 
medRxiv preprint doi: https://doi.org/10.1101/2020.08.05.20169136; this version posted August 6, 2020. The copyright holder for this preprint (which was not certified by peer review) is the author/funder, who has granted medRxiv a license to display the preprint in

It is made available under a CC-BY-NC-ND 4.0 International license.

Circulation Research, 123(10), 1127-1142. https://doi.org/10.1161/CIRCRESAHA.118.312804

Kimura, I., Ichimura, A., Ohue-Kitano, R., \& Igarashi, M. (2020). Free fatty acid receptors in health and disease. Physiological Reviews, 100(1), 171-210. https://doi.org/10.1152/physrev.00041.2018

Kraakman, M. J., Lee, M. K. S., Al-Sharea, A., Dragoljevic, D., Barrett, T. J., Montenont, E., Basu, D., Heywood, S., Kammoun, H. L., Flynn, M., Whillas, A., Hanssen, N. M. J., Febbraio, M. A., Westein, E., Fisher, E. A., Chin-Dusting, J., Cooper, M. E., Berger, J. S., Goldberg, I. J., ... Murphy, A. J. (2017). Neutrophil-derived S100 calcium-binding proteins A8/A9 promote reticulated thrombocytosis and atherogenesis in diabetes. Journal of Clinical Investigation, 127(6), 2133-2147. https://doi.org/10.1172/JCl92450

Kuleshov, M. V, Jones, M. R., Rouillard, A. D., Fernandez, N. F., Duan, Q., Wang, Z., Koplev, S., Jenkins, S. L., Jagodnik, K. M., Lachmann, A., Mcdermott, M. G., Monteiro, C. D., Gundersen, G. W., \& Ma'ayan, A. (2016). Enrichr: a comprehensive gene set enrichment analysis web server 2016 update. Nucleic Acids Research, 44. https://doi.org/10.1093/nar/gkw377

Lee, S. U., In, H. J., Kwon, M. S., Park, B., Jo, M., Kim, M.-O., Cho, S., Lee, S., Lee, H.-J., Kwak, Y. S., \& Kim, S. (2013). $\beta$-Arrestin 2 Mediates G Protein-Coupled Receptor 43 Signals to Nuclear FactorKB. Biological and Pharmaceutical Bulletin, 36(11), 1754-1759. https://doi.org/10.1248/bpb.b1300312

Leonard, D., Svenungsson, E., Sandling, J. K., Berggren, O., Jönsen, A., Bengtsson, C., Wang, C., Jensen-Urstad, K., Granstam, S. O., Bengtsson, A. A., Gustafsson, J. T., Gunnarsson, I., Rantapää-Dahlqvist, S., Nordmark, G., Eloranta, M. L., Syvänen, A. C., \& Rönnblom, L. (2013). Coronary heart disease in systemic lupus erythematosus is associated with interferon regulatory factor-8 gene variants. Circulation: Cardiovascular Genetics, 6(3), 255-263. https://doi.org/10.1161/CIRCGENETICS.113.000044

Li, B., Xia, Y., \& Hu, B. (2020). Infection and atherosclerosis: TLR-dependent pathways. In Cellular and Molecular Life Sciences (Vol. 77, Issue 14, pp. 2751-2769). Springer. https://doi.org/10.1007/s00018-020-03453-7

Lichtenstein, L., Serhan, N., Espinosa-Delgado, S., Fabre, A., Annema, W., Tietge, U. J. F., Robaye, B., Boeynaems, J. M., Laffargue, M., Perret, B., \& Martinez, L. O. (2015). Increased atherosclerosis in P2Y13/apolipoprotein e double-knockout mice: Contribution of P2Y13 to reverse cholesterol transport. Cardiovascular Research, 106(2), 314-323. https://doi.org/10.1093/cvr/cvv109

Louie, R., Gage, M., Patel, A., Yona, S., Castrillo, A., \& Pineda-Torra, I. (2019). Myeloid Interferon Regulatory Factor 8 Deficiency Prevents The Development Of Atherosclerosis. Atherosclerosis, 287, e18-e19. https://doi.org/10.1016/j.atherosclerosis.2019.06.052

Ma, W. T., Gao, F., Gu, K., \& Chen, D. K. (2019). The role of monocytes and macrophages in autoimmune diseases: A comprehensive review. In Frontiers in Immunology (Vol. 10, Issue MAY, p. 1140). Frontiers Media S.A. https://doi.org/10.3389/fimmu.2019.01140

Mao, Y. M., Zhao, C. N., Leng, J., Leng, R. X., Ye, D. Q., Zheng, S. G., \& Pan, H. F. (2019). Interleukin13: A promising therapeutic target for autoimmune disease. In Cytokine and Growth Factor Reviews (Vol. 45, pp. 9-23). Elsevier Ltd. https://doi.org/10.1016/j.cytogfr.2018.12.001

Márquez, E. J., Chung, C. han, Marches, R., Rossi, R. J., Nehar-Belaid, D., Eroglu, A., Mellert, D. J., Kuchel, G. A., Banchereau, J., \& Ucar, D. (2020). Sexual-dimorphism in human immune system aging. Nature Communications, 11(1), 1-17. https://doi.org/10.1038/s41467-020-14396-9

Metsalu, T., \& Vilo, J. (2015). ClustVis: a web tool for visualizing clustering of multivariate data using Principal Component Analysis and heatmap. Web Server Issue Published Online, 43. https://doi.org/10.1093/nar/gkv468

Moore, K. J., Sheedy, F. J., \& Fisher, E. A. (2013). Macrophages in atherosclerosis: A dynamic balance. In Nature Reviews Immunology (Vol. 13, Issue 10, pp. 709-721). Nature Publishing Group. https://doi.org/10.1038/nri3520

Morimoto, S., Tokano, Y., Kaneko, H., Nozawa, K., Amano, H., \& Hashimoto, H. (2001). The increased interleukin-13 patients with systemic lupus erythematosus: Relations to other Th1-, Th2-related cytokines and clinical findings. Autoimmunity, 34(1), 19-25.

https://doi.org/10.3109/08916930108994122

Nishimoto, N., Yoshizaki, K., Miyasaka, N., Yamamoto, K., Kawai, S., Takeuchi, T., Hashimoto, J., Azuma, J., \& Kishimoto, T. (2004). Treatment of rheumatoid arthritis with humanized antiinterleukin-6 receptor antibody: A multicenter, double-blind, placebo-controlled trial. Arthritis and Rheumatism, 50(6), 1761-1769. https://doi.org/10.1002/art.20303

Obermoser, G., \& Pascual, V. (2010). The interferon-alpha signature of systemic lupus erythematosus. Lupus, 19(9), 1012-1019. https://doi.org/10.1177/0961203310371161 
medRxiv preprint doi: https://doi.org/10.1101/2020.08.05.20169136; this version posted August 6, 2020. The copyright holder for this preprint (which was not certified by peer review) is the author/funder, who has granted medRxiv a license to display the preprint in perpetuity.

It is made available under a CC-BY-NC-ND 4.0 International license .

Olofsen, P. A., \& Touw, I. P. (2020). RUNX1 Mutations in the Leukemic Progression of Severe Congenital Neutropenia. In Molecules and cells (Vol. 43, Issue 2, pp. 139-144). NLM (Medline). https://doi.org/10.14348/molcells.2020.0010

Panwar, B., Schmiedel, B. J., Liang, S., White, B., Rodriquez, E., Kalunian, K., McKnight, A. J., Soloff, R., Seumois, G., Vijayanand, P., \& Ay, F. (2020). Integrative transcriptomic analysis of SLE reveals IFN-driven cross-talk between immune cells. BioRxiv, 2020.04.27.065227. https://doi.org/10.1101/2020.04.27.065227

Peng, W. H., Jian, W. X., Li, H. L., Hou, L., Wei, Y. D., Li, W. M., \& Xu, Y. W. (2011). Increased serum myeloid-related protein $8 / 14$ level is associated with atherosclerosis in type 2 diabetic patients. Cardiovascular Diabetology, 10(1), 1-7. https://doi.org/10.1186/1475-2840-10-41

Petri, M., Orbai, A. M., Alarcõn, G. S., Gordon, C., Merrill, J. T., Fortin, P. R., Bruce, I. N., Isenberg, D., Wallace, D. J., Nived, O., Sturfelt, G., Ramsey-Goldman, R., Bae, S. C., Hanly, J. G., SánchezGuerrero, J., Clarke, A., Aranow, C., Manzi, S., Urowitz, M., ... Magder, L. S. (2012). Derivation and validation of the systemic lupus international collaborating clinics classification criteria for systemic lupus erythematosus. Arthritis and Rheumatism, 64(8), 2677-2686. https://doi.org/10.1002/art.34473

Pi, S., Mao, L., Chen, J., Shi, H., Liu, Y., Guo, X., Li, Y., Zhou, L., He, H., Yu, C., Liu, J., Dang, Y., Xia, Y., He, Q., Jin, H., Li, Y., Hu, Y., Miao, Y., Yue, Z., \& Hu, B. (2020). The P2RY12 receptor promotes VSMC-derived foam cell formation by inhibiting autophagy in advanced atherosclerosis. Autophagy. https://doi.org/10.1080/15548627.2020.1741202

Robinson, G. A., Waddington, K. E., Adriani, M., Radziszewska, A., Peckham, H., Isenberg, D. A., loannou, Y., Ciurtin, C., Pineda-Torra, I., \& Jury, E. C. (2019). Sex differences in autoimmunity could be associated with altered regulatory $\mathrm{T}$ cell phenotype and lipoprotein metabolism. BioRxiv, 760975. https://doi.org/10.1101/760975

Rönnblom, L., \& Alm, G. V. (2001). A pivotal role for the natural interferon $\alpha$-producing cells (plasmacytoid dendritic cells) in the pathogenesis of lupus. In Journal of Experimental Medicine (Vol. 194, Issue 12, pp. F59-F64). The Rockefeller University Press. https://doi.org/10.1084/jem.194.12.f59

Ryu, H., Kim, J., Kim, D., Lee, J. E., \& Chung, Y. (2019). Cellular and Molecular Links between Autoimmunity and Lipid Metabolism. In Molecules and cells (Vol. 42, Issue 11, pp. 747-754). NLM (Medline). https://doi.org/10.14348/molcells.2019.0196

Salem, S., Salem, D., \& Gros, P. (2020). Role of IRF8 in immune cells functions, protection against infections, and susceptibility to inflammatory diseases. In Human Genetics (Vol. 139, Issues 6-7, pp. 707-721). Springer. https://doi.org/10.1007/s00439-020-02154-2

Schoenfeld, S. R., Kasturi, S., \& Costenbader, K. H. (2013). The epidemiology of atherosclerotic cardiovascular disease among patients with SLE: A systematic review. Seminars in Arthritis and Rheumatism, 43(1), 77-95. https://doi.org/10.1016/j.semarthrit.2012.12.002

Schrottmaier, W. C., Kral, J. B., Badrnya, S., \& Assinger, A. (2015). Aspirin and P2Y12 inhibitors in platelet-mediated activation of neutrophils and monocytes. Thrombosis and Haemostasis, 114(3), 478-489. https://doi.org/10.1160/TH14-11-0943

Sha, Y., \& Markovic-Plese, S. (2011). A role of IL-1R1 signaling in the differentiation of Th17 cells and the development of autoimmune diseases. In Self/Nonself - Immune Recognition and Signaling (Vol. 2, Issue 1, pp. 35-42). Taylor \& Francis. https://doi.org/10.4161/self.2.1.15639

Smith, E., Croca, S., Waddington, K. E., Sofat, R., Griffin, M., Nicolaides, A., Isenberg, D. A., Torra, I. P., Rahman, A., \& Jury, E. C. (2016). Cross-talk between iNKT cells and monocytes triggers an atheroprotective immune response in SLE patients with asymptomatic plaque. Science Immunology, 1(6). https://doi.org/10.1126/sciimmunol.aah4081

Swirski, F. K., Libby, P., Aikawa, E., Alcaide, P., Luscinskas, F. W., Weissleder, R., \& Pittet, M. J. (2007). Ly-6Chi monocytes dominate hypercholesterolemia-associated monocytosis and give rise to macrophages in atheromata. Journal of Clinical Investigation, 117(1), 195-205. https://doi.org/10.1172/JCl29950

Szklarczyk, D., Gable, A. L., Lyon, D., Junge, A., Wyder, S., Huerta-Cepas, J., Simonovic, M., Doncheva, N. T., Morris, J. H., Jensen, L. J., \& Von Mering, C. (2018). STRING v11: protein-protein association networks with increased coverage, supporting functional discovery in genome-wide experimental datasets. Nucleic Acids Research, 47, 607-613. https://doi.org/10.1093/nar/gky1131

Tabas, I., \& Lichtman, A. H. (2017). Monocyte-Macrophages and T Cells in Atherosclerosis. In Immunity (Vol. 47, Issue 4, pp. 621-634). Cell Press. https://doi.org/10.1016/j.immuni.2017.09.008

Tanaka, T., Narazaki, M., \& Kishimoto, T. (2014). II-6 in inflammation, Immunity, And disease. Cold 
medRxiv preprint doi: https://doi.org/10.1101/2020.08.05.20169136; this version posted August 6, 2020. The copyright holder for this preprint (which was not certified by peer review) is the author/funder, who has granted medRxiv a license to display the preprint in It is made available under a CC-BY-NC-ND 4.0 International license .

Spring Harbor Perspectives in Biology, 6(10), 16295-16296.

https://doi.org/10.1101/cshperspect.a016295

Voisset, E., Brenet, F., Lopez, S., \& de Sepulveda, P. (2020). SRC-Family Kinases in Acute Myeloid Leukaemia and Mastocytosis. Cancers, 12(7), 1996. https://doi.org/10.3390/cancers12071996

Wallentin, L., Becker, R. C., Budaj, A., Cannon, C. P., Emanuelsson, H., Held, C., Horrow, J., Husted, S., James, S., Katus, H., Mahaffey, K. W., Scirica, B. M., Skene, A., Steg, P. G., Storey, R. F., \& Harrington, R. A. (2009). Ticagrelor versus Clopidogrel in Patients with Acute Coronary Syndromes. New England Journal of Medicine, 361(11), 1045-1057. https://doi.org/10.1056/NEJMoa0904327

Waterhouse, D. F., Cahill, R. A., Sheehan, F., \& McCreery, C. J. (2008). Prediction of calculated future cardiovascular disease by monocyte count in an asymptomatic population. Vascular Health and Risk Management, 4(1), 177-187. https://doi.org/10.2147/vhrm.2008.04.01.177

Wenger, N. K. (2018). Sauce for the Goose Versus Sauce for the Gander: Should Men and Women Play the Same Game But With Different Rules? Circulation, 137(8), 791-793. https://doi.org/10.1161/CIRCULATIONAHA.118.033168

Willemsen, L., \& Winther, M. P. (2020). Macrophage subsets in atherosclerosis as defined by single-cell technologies. The Journal of Pathology, 250(5), 705-714. https://doi.org/10.1002/path.5392

Xiao, X., Yang, C., Qu, S. L., Shao, Y. D., Zhou, C. Y., Chao, R., Huang, L., \& Zhang, C. (2020). S100 proteins in atherosclerosis. In Clinica Chimica Acta (Vol. 502, pp. 293-304). Elsevier B.V. https://doi.org/10.1016/j.cca.2019.11.019

Yakubenko, V. P., Hsi, L. C., Cathcart, M. K., \& Bhattacharjee, A. (2013). From macrophage interleukin13 receptor to foam cell formation: Mechanisms for $\alpha \mathrm{m} \beta 2$ integrin interference. Journal of Biological Chemistry, 288(4), 2778-2788. https://doi.org/10.1074/jbc.M112.381343

Yao, Y., Higgs, B. W., Morehouse, C., Reyes, M. de los, Trigona, W., Brohawn, P., White, W., Zhang, J., White, B., Coyle, A. J., Kiener, P. A., \& Jallal, B. (2009). Development of Potential

Pharmacodynamic and Diagnostic Markers for Anti-IFN- $\alpha$ Monoclonal Antibody Trials in Systemic Lupus Erythematosus. Human Genomics and Proteomics : HGP, 2009. https://doi.org/10.4061/2009/374312

Ytterberg, S. R., \& Schnitzer, T. J. (1982). Serum interferon levels in patients with systemic lupus erythematosus. Arthritis \& Rheumatism, 25(4), 401-406. https://doi.org/10.1002/art.1780250407

Zhou, G., Soufan, O., Ewald, J., Hancock, R. E. W., Basu, N., \& Xia, J. (2019). NetworkAnalyst 3.0: a visual analytics platform for comprehensive gene expression profiling and meta-analysis. Web Server Issue Published Online, 47. https://doi.org/10.1093/nar/gkz240

Zhou, J., Cheng, M., Wu, M., Boriboun, C., Jujo, K., Xu, S., Zhao, T. C., Tang, Y. L., Kishore, R., \& Qin, G. (2013). Contrasting roles of E2F2 and E2F3 in endothelial cell growth and ischemic angiogenesis. Journal of Molecular and Cellular Cardiology, 60(1), 68-71. https://doi.org/10.1016/j.yjmcc.2013.04.009

Zhou, Y., Zhou, B., Pache, L., Chang, M., Khodabakhshi, A. H., Tanaseichuk, O., Benner, C., \& Chanda, S. K. (2019). Metascape provides a biologist-oriented resource for the analysis of systems-level datasets. Nature Communications, 10(1). https://doi.org/10.1038/s41467-019-09234-6 
medRxiv preprint doi: https://doi.org/10.1101/2020.08.05.20169136; this version posted August 6, 2020. The copyright holder for this preprint (which was not certified by peer review) is the author/funder, who has granted medRxiv a license to display the preprint in

It is made available under a CC-BY-NC-ND 4.0 International license .

\section{Figure 1}

A

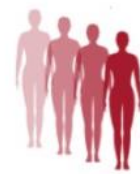

UCLH Study groups: 1.SLE-NP:

remain lesion free at $2^{\text {nd }}$ scan

2. SLE-P.

show pre-clinical plaques at $1^{\text {st }} \& 2^{\text {nd }}$ scan
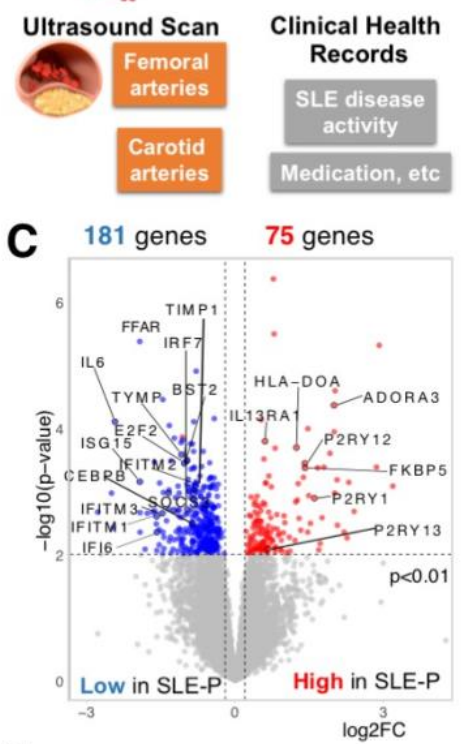

E G1/S Phase / Cell cycle E2F2 TYMP

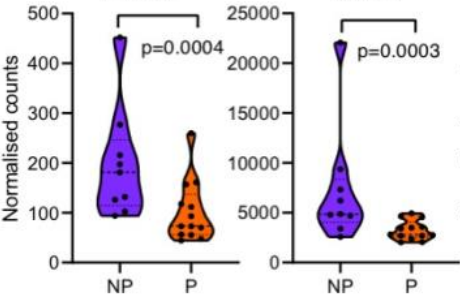

F Purinergic receptors
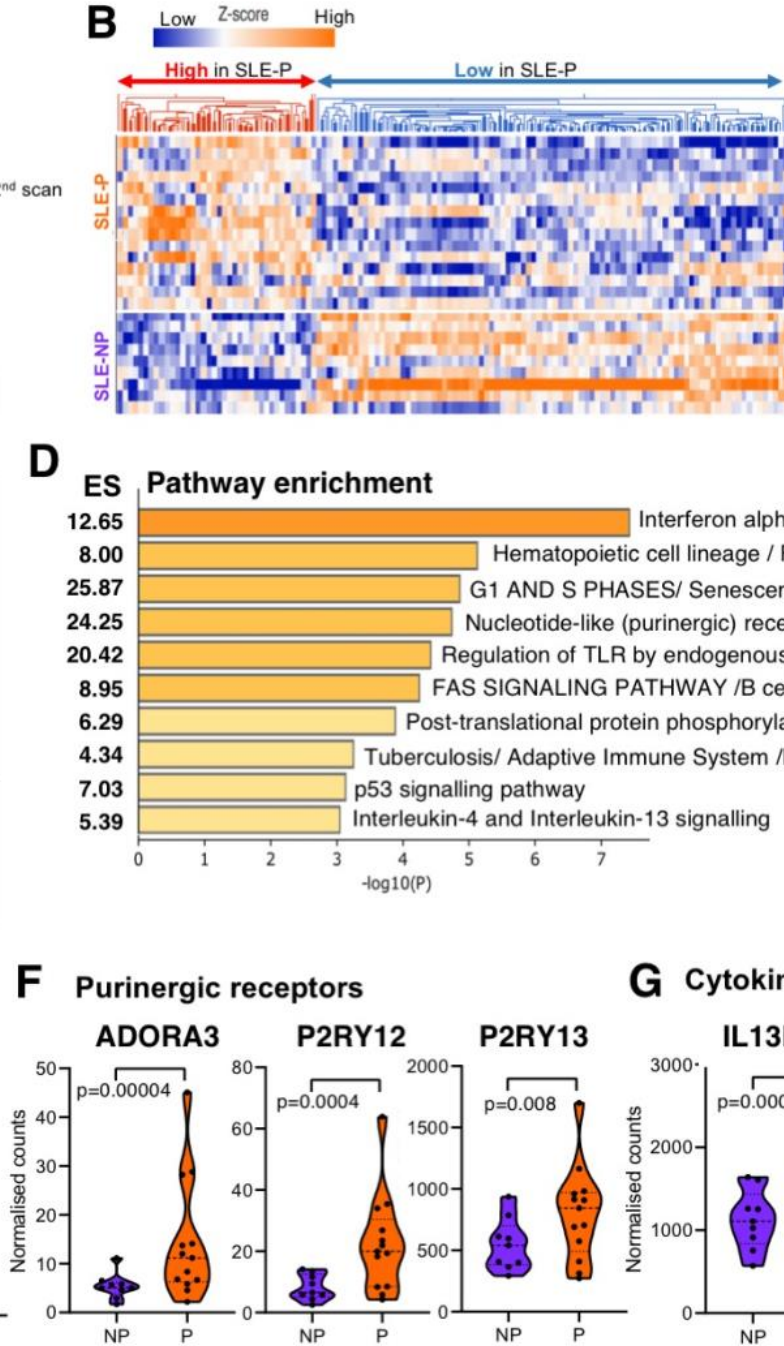

G Cytokine signaling
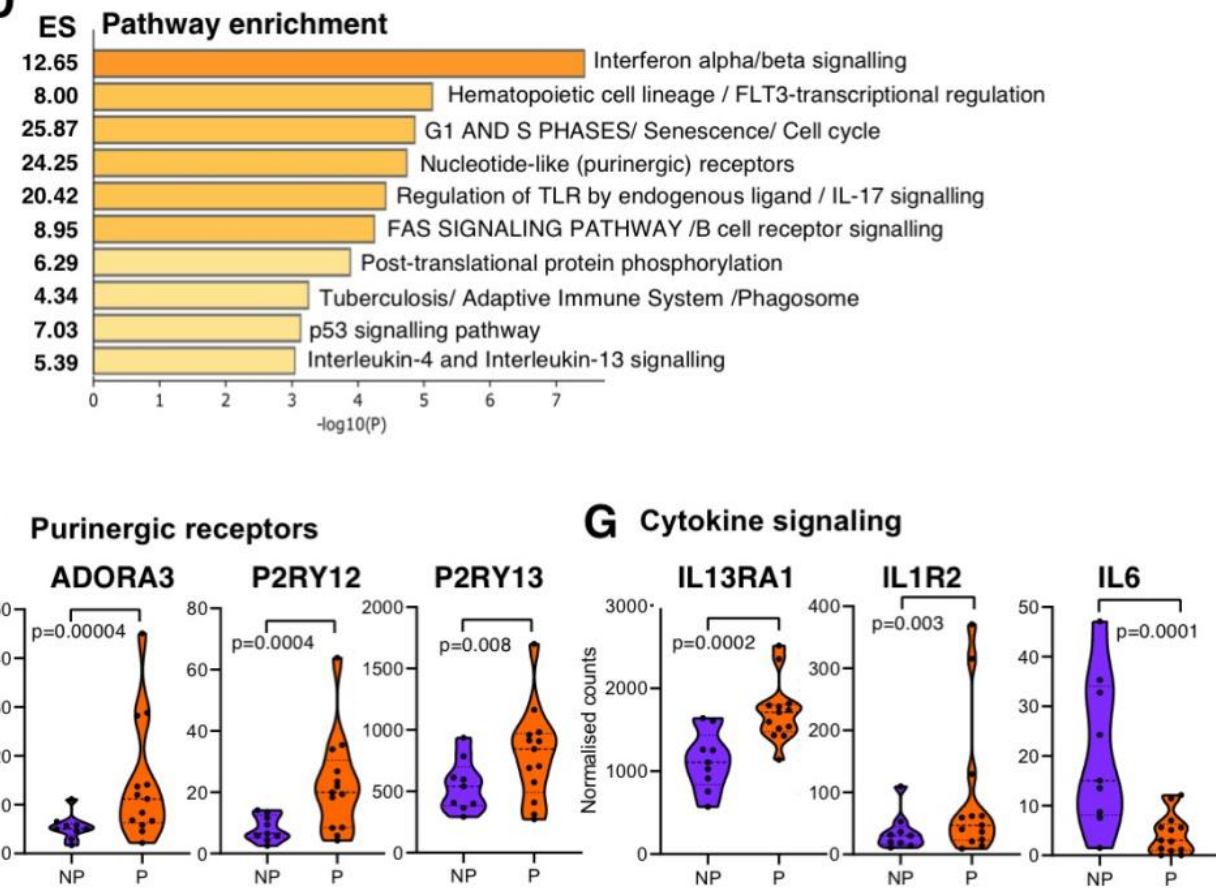

$\mathbf{J}$

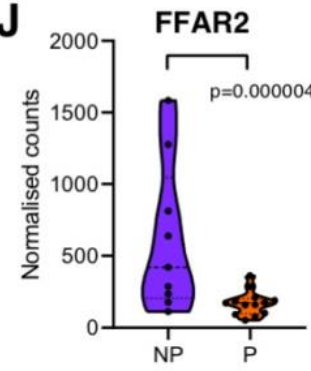

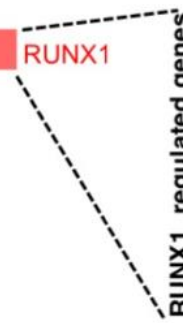

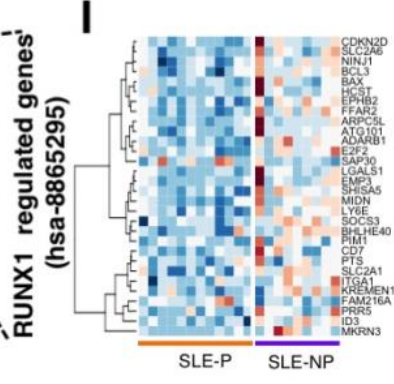

$\mathrm{H}_{\mathrm{p}}$ ES Transcription factor regulation 0.00112 .19

0.0059 .11

0.0206 .90

0.0276 .13

0.0315 .41

0.0314 .72

$0.034 \quad 4.73$

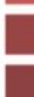

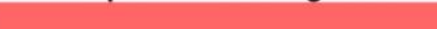

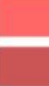
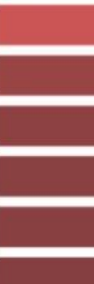

SMC3

SP1 CEBPD SPI1 ZBTB7A CTCF

Women with SLE and pre-clinical atherosclerosis (SLE-P) show distinctive patterns of gene expression compared to those without atherosclerosis (SLE-NP).

A. Summary of study groups.

B. Clustered heatmap of CD14+ monocyte normalized gene counts showing genes differentially expressed (DE) genes

( $\geq 1.5$ fold change, $p \leq 0.01$ ) analysed by RNA-seq (SLE-P, $n=15$; SLE-NP, $n=9$ ).

C. Volcano plot illustrating DE genes clustered in B.

D. Pathway enrichment analysis of DE genes plotted by significance (-log10 p-value) with enrichment scores (ES) shown. Annotations refer to KEGG, Reactome and Canonical derived pathways.

E-G. Violin plots for representative genes in the indicated pathways of the normalized gene counts. Statistical analysis from Deseq2 DE analysis shown. Bar represents the median.

H. Enrichment analysis (EnrichR: ChEA and ENCODE) of transcription factors associated with DE genes in B \&D.

I. Heatmap of normalized gene counts (natural $\log x+1$ transformed) for RUNX1 associated genes $(n=30)$ in SLE-P and SLEP-NP groups.

J. Violin plot of the normalized gene counts for most significant DE gene in the RUNX1-regulated pathways. Statistical analysis from Deseq2 analysis shown. Bar represents the median. 
medRxiv preprint doi: https://doi.org/10.1101/2020.08.05.20169136; this version posted August 6, 2020. The copyright holder for this preprint (which was not certified by peer review) is the author/funder, who has granted medRxiv a license to display the preprint in perpetuity.

It is made available under a CC-BY-NC-ND 4.0 International license .

\section{Figure 2}

A IFN20-GSEA

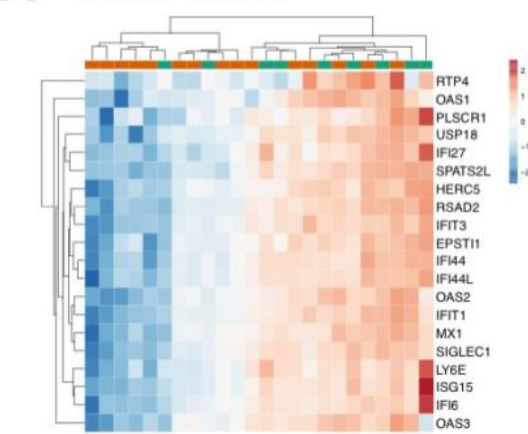

B IFN-VITAL

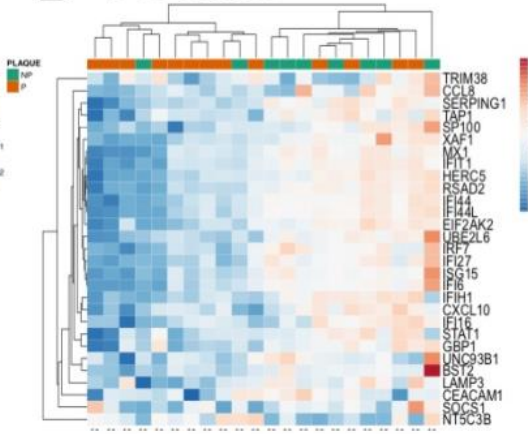

C IfN-THIS Study

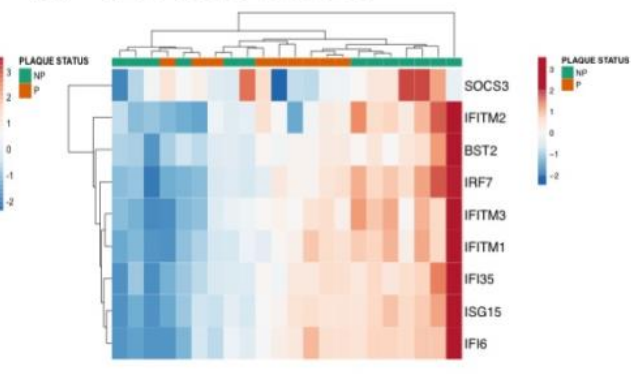

D

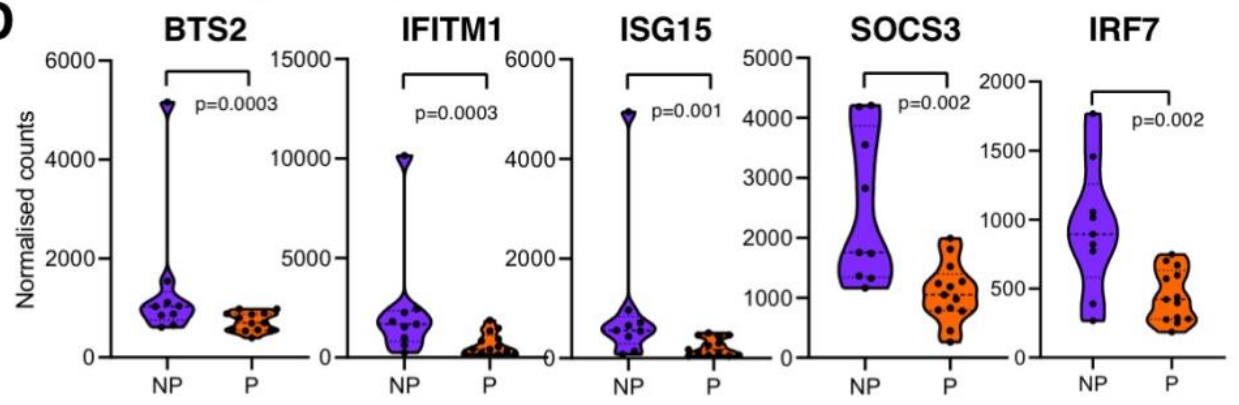

$\mathbf{E}$

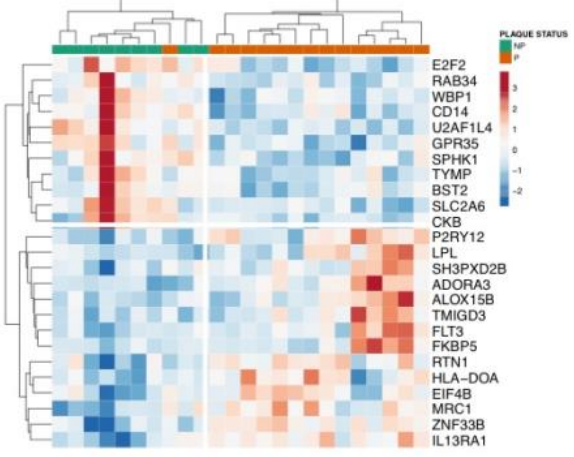

$\mathbf{F}$

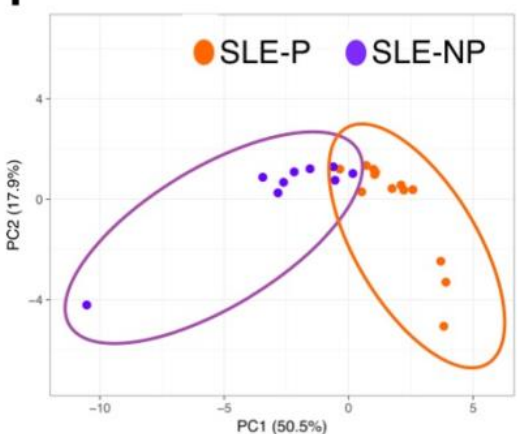

Interferon signatures do not distinguish the presence of atherosclerosis in women with SLE.

A-C. Unsupervised clustering heatmaps of CD14+ monocyte normalized counts in SLE-P vs SLE-NP groups of the indicated IFN signatures: A, IFN20-GSEA (Ay et al., 2020); B, IFN-Vital (Vital et al., 2018); C, IFN signature identified in Fig. B,E.

D. Violin plots for representative genes in the IFN signature shown in C showing the normalized gene counts in SLE-P (orange) and SLE-NP (purple). Statistical analysis from Deseq2 DE analysis shown. Bar represents the median.

E. Unsupervised clustering heatmap of top significant DE genes between SLE-P vs SLE-NP groups showing better clustering of the presence of atherosclerosis.

F. Principal component analysis (PCA) of top significant DE genes shown in E. PCA X and Y axis show principal component 1 and 2 that explain $50.5 \%$ and $17.9 \%$ of the total variance, respectively. 
medRxiv preprint doi: https://doi.org/10.1101/2020.08.05.20169136; this version posted August 6, 2020. The copyright holder for this preprint (which was not certified by peer review) is the author/funder, who has granted medRxiv a license to display the preprint in perpetuity.

It is made available under a CC-BY-NC-ND 4.0 International license

\section{Figure 3}

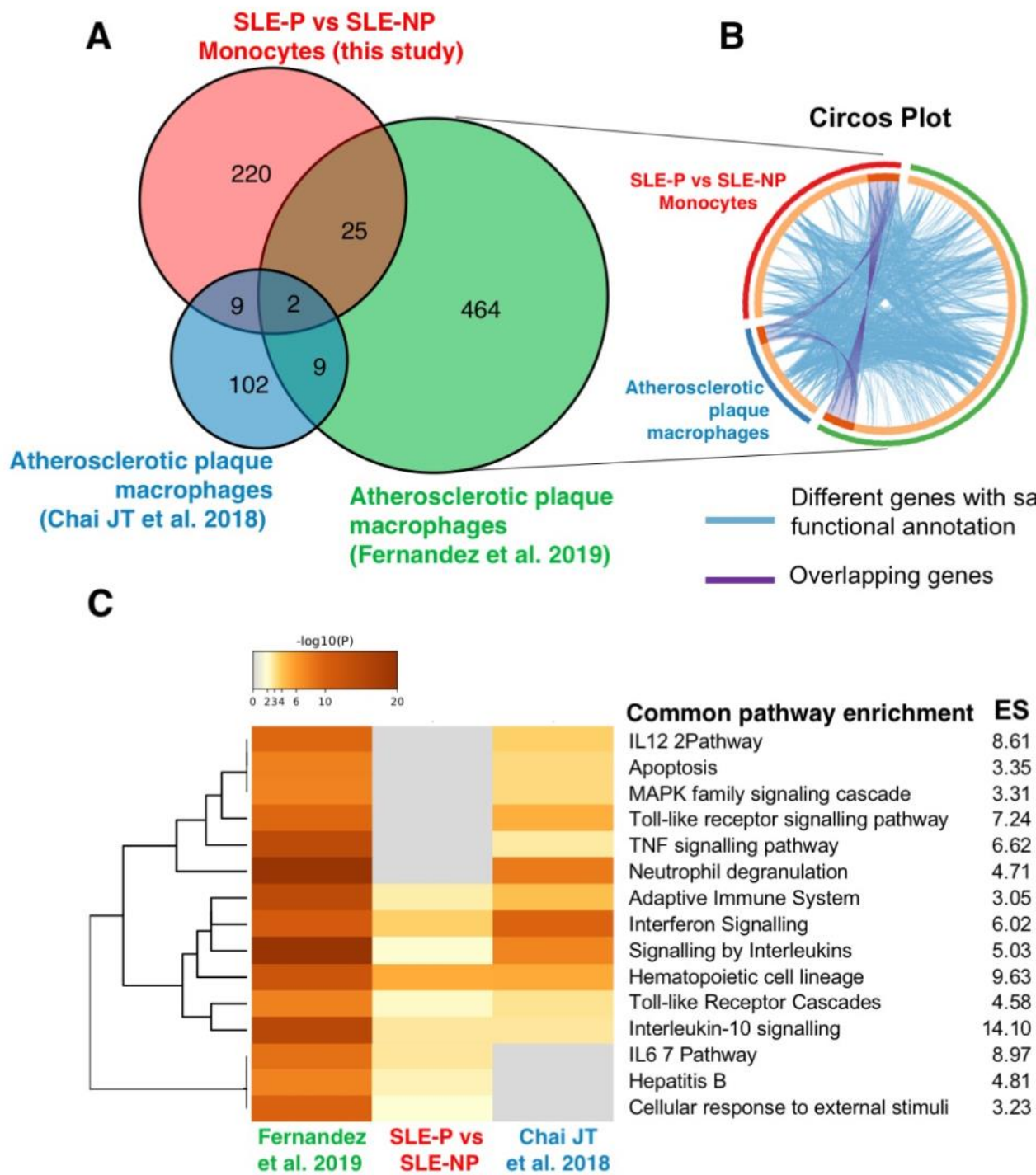

Overlapping signalling pathways exist between SLE-P monocytes and reported atherosclerotic plaque macrophages. A. Venn diagram comparing the DE genes identified Fig.1B (red), enriched genes in asymptomatic plaque macrophages (Fernandez et al. 2016) (green) and (Chai JT et al. 2018) (blue). Numbers represent the number of genes in each overlapping or non-overlapping group.

B. Circos plot highlighting the overlap between the indicated datasets: Blue lines link DE genes sharing the same gene ontology, whereas purple lines link overlapping genes.

C. Pathway enrichment analysis of common DE genes plotted by significance (-log10 p-value) with enrichment scores (ES) shown. Annotations refer to KEGG, Reactome and Canonical derived pathways. 
medRxiv preprint doi: https://doi.org/10.1101/2020.08.05.20169136; this version posted August 6, 2020. The copyright holder for this preprint (which was not certified by peer review) is the author/funder, who has granted medRxiv a license to display the preprint in perpetuity.

It is made available under a CC-BY-NC-ND 4.0 International license .

\section{Figure 4}

A

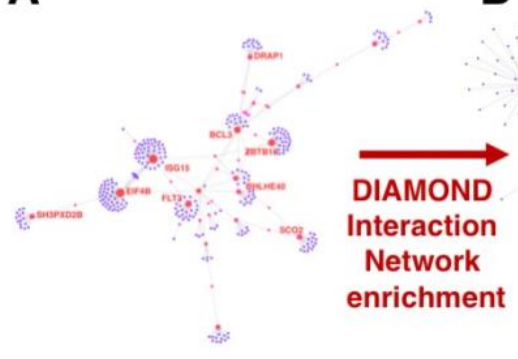

D

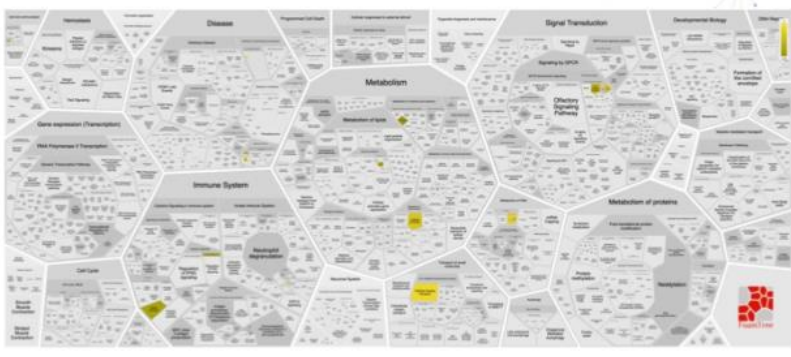

B

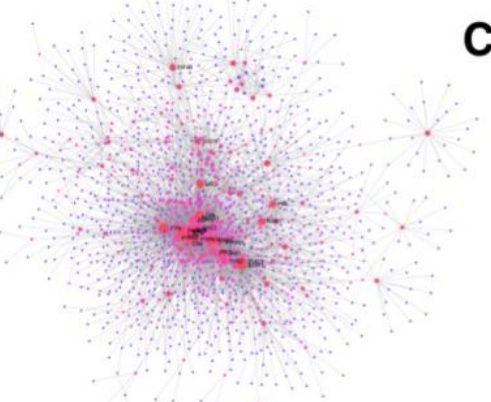

\section{$C_{\log (p)}$ ES Pathway}

-100.0070 .49 IFN gamma signalling

$-100.00 \quad 53.27$ IFN alpha/beta signalling

-56.3281 .91 Measles

-54.4631 .81 Adaptive Immune System

-43.10 9.63 PID TCR PATHWAY

-36.8143 .52 Th17 cell differentiation

$-34.26 \quad 27.71 \mathrm{IL}-3, \mathrm{IL}-5$ and GM-CSF signalling

-21.2446 .33 Antiviral mechanism by IFN-stimulated genes

\section{$\mathbf{F}$}

E

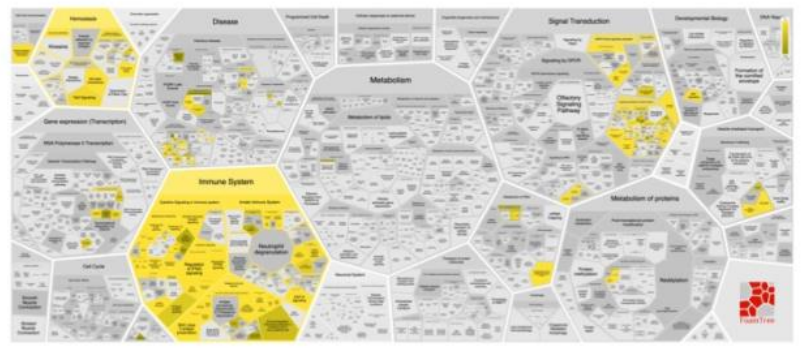

3.82E-14 344.28

$5.85 \mathrm{E}-07 \quad 44.89$

$5.04 \mathrm{E}-06 \quad 33.23$

$1.29 \mathrm{E}-0528.55$

$2.9 \mathrm{E}-04 \quad 21.4$

4.13E-03 10.94

$6.98 \mathrm{E}-03 \quad 10.78$

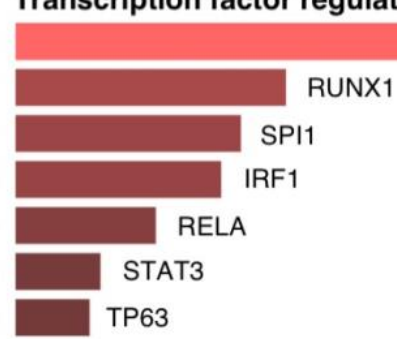

IRF8

Enhanced interaction network analysis identifies pathways involved in adaptive immune system

A. Protein-protein interaction (PPI) network (Network Analyst, STRINGdb) of DE genes ( $\geq 1.5$ fold change, $p \leq 0.001, n D E$ genes $=66$ ) analysed by RNA-seq as shown in Fig.1B .

B. PPI network of DIAMOnD-extended DE list $(n=268)$.

C. Pathway enrichment analysis (Metascape) of genes in B.

D. ReacFoam (Reactome) visualization of pathway enrichment analysis using Reactome curation plotted against biological process using genes in A. Yellow indicates enriched pathways.

E. Pathway enrichment analysis as in D using DIAMOnD-extended gene list sown in B.

F. Enrichment analysis (EnrichR: ChEA and ENCODE) of transcription factors associated with DIAMOnD-extended DE genes shown in B. 
medRxiv preprint doi: https://doi.org/10.1101/2020.08.05.20169136; this version posted August 6, 2020. The copyright holder for this preprint (which was not certified by peer review) is the author/funder, who has granted medRxiv a license to display the preprint in It is made available under a CC-BY-NC-ND 4.0 International license.

Table 1: Metascape analysis of enriched Reactome/KEGG/Canonical/Corum pathways in differentially expressed genes in SLE-P vs SLE-NP monocytes

\begin{tabular}{|c|c|c|c|c|c|}
\hline Pathway & Pathway ID & Genes & $\begin{array}{l}\log 10 \\
\text { (p) }\end{array}$ & $\begin{array}{l}\log 10 \\
(q)\end{array}$ & $\begin{array}{l}\text { Enrichment } \\
\text { score }\end{array}$ \\
\hline $\begin{array}{l}\text { Interferon } \\
\text { alpha/beta } \\
\text { signaling }\end{array}$ & hsa909733 & $\begin{array}{l}\text { BST2,IFI6,IFI35,IRF7,IFIT } \\
\text { M1,SOCS3,ISG15,IFITM3 } \\
\text {,IFITM2 }\end{array}$ & -7.425 & -3.910 & 12.65 \\
\hline $\begin{array}{l}\text { Hematopoieti } \\
\text { c cell lineage } \\
\text { / FLT3- } \\
\text { transcriptiona } \\
\text { I regulation }\end{array}$ & hsa04640 & $\begin{array}{l}\text { CD1E,CD7,CD14,FLT3,H } \\
\text { LA- } \\
\text { DOA,IL6,ITGA1,IL1R2,BC } \\
\text { L2A1,CDKN1A,CEBPB,Z } \\
\text { BTB16 }\end{array}$ & -5.127 & -1.913 & 8.00 \\
\hline $\begin{array}{l}\text { G1 AND S } \\
\text { PHASES }\end{array}$ & M1529 & $\begin{array}{l}\text { CDKN1A,E2F1,E2F2,NXT } \\
\text { 1,CDKN2D,CEBPB,ID1,IL } \\
\text { 6,CBX6,H2AJ,SFTPD,AT } \\
\text { F3,BAX,BCL2A1,CD82,T } \\
\text { YMP,HLA- } \\
\text { DOA,SLC2A1,IL1R2,IRF7 } \\
\text {,PDGFC,FKBP5,PSMB9, } \\
\text { TUBA1A,GADD45B }\end{array}$ & -4.861 & -1.828 & 25.87 \\
\hline $\begin{array}{l}\text { Nucleotide- } \\
\text { like } \\
\text { (purinergic) } \\
\text { receptors }\end{array}$ & hsa418038 & $\begin{array}{l}\text { ADORA3,P2RY1,P2RY13 } \\
\text {,P2RY12,GPR35,FFAR2, } \\
\text { HCAR3,UTS2,GHRL,HCA } \\
\text { R2,ADM }\end{array}$ & -4.740 & -1.828 & 24.25 \\
\hline $\begin{array}{l}\text { Regulation of } \\
\text { TLR by } \\
\text { endogenous } \\
\text { ligand / IL-17 } \\
\text { signalling }\end{array}$ & hsa5686938 & $\begin{array}{l}\text { CD14,S100A8,S100A9,S } \\
\text { FTPD,CEBPB,IL6,TRAF4, } \\
\text { MUC5B,IRF7,NFKBIB }\end{array}$ & -4.422 & -1.607 & 20.42 \\
\hline $\begin{array}{l}\text { FAS } \\
\text { SIGNALING } \\
\text { PATHWAY / } \\
\text { B cell } \\
\text { receptor } \\
\text { signalling } \\
\end{array}$ & M8873 & $\begin{array}{l}\text { BAX,CD7,EPHB2,HSPB1, } \\
\text { NFKBIB,NFKBIE,CD79B, } \\
\text { FCGR2B,IFITM1,BCL2A1 } \\
\text {,SLC2A1,SOCS3 }\end{array}$ & -4.251 & -1.515 & 8.95 \\
\hline $\begin{array}{l}\text { Post- } \\
\text { translational } \\
\text { protein } \\
\text { phosphorylati } \\
\text { on }\end{array}$ & hsa8957275 & $\begin{array}{l}\text { IL6,LGALS1,TIMP1,FSTL } \\
\text { 3,CKAP4,SHISA5,FAM20 } \\
\text { A }\end{array}$ & -3.883 & -1.214 & 6.29 \\
\hline $\begin{array}{l}\text { Tuberculosis } \\
\text { / Adaptive } \\
\text { Immune } \\
\text { System / } \\
\text { Phagosome }\end{array}$ & hsa05152 & $\begin{array}{l}\text { BAX,CD14,CEBPB,FCGR } \\
\text { 2B,HLA- } \\
\text { DOA,IL6,MRC1,SPHK1,C } \\
\text { D80,CD79B,NFKBIB,NFK } \\
\text { BIE,PSMB9,NECTIN2,SF } \\
\text { TPD,ZBTB16,TUBA1A,IFI } \\
\text { TM1,SOCS3,HCST,PRR5 }\end{array}$ & -3.252 & -0.952 & 4.34 \\
\hline $\begin{array}{l}\text { p53 signaling } \\
\text { pathway }\end{array}$ & hsa04115 & $\begin{array}{l}\text { BAX,CDKN1A,CD82,GAD } \\
\text { D45B,SHISA5,BIN1,TUB } \\
\text { A1A }\end{array}$ & -3.134 & -0.875 & 7.03 \\
\hline $\begin{array}{l}\text { Interleukin-4 } \\
\text { and } \\
\text { Interleukin-13 } \\
\text { signaling }\end{array}$ & hsa6785807 & $\begin{array}{l}\text { CDKN1A,IL6,IL13RA1,PI } \\
\text { M1,TIMP1,SOCS3,CEBP } \\
\text { B,CD80,IL1R2,ATF3,DUS } \\
\text { P8,HLA- } \\
\text { DOA,LGALS9,NFKBIB,P } \\
\text { SMB9 }\end{array}$ & -3.046 & -0.854 & 5.39 \\
\hline
\end{tabular}


medRxiv preprint doi: https://doi.org/10.1101/2020.08.05.20169136; this version posted August 6, 2020. The copyright holder for this preprint (which was not certified by peer review) is the author/funder, who has granted medRxiv a license to display the preprint in It is made available under a CC-BY-NC-ND 4.0 International license.

Top 10 clusters with representative enriched terms (Pathway) and KEGG Functional Sets, KEGG Pathway, Reactome Gene Sets, Canonical Pathways, CORUM, TRRUST, DisGeNET and PaGenBase annotation identifier (Pathway ID). Genes include all genes enriched in pathway from differential gene expression seed list. $\log 10(p)$ refers to the hypergeometric distribution test statistic in log base 10. Log10(q) refers to the multi-test adjusted $p$-value in log base 10. Enrichment score indicates how many fold more pathway members belong to a given pathway than expected by chance. 
medRxiv preprint doi: https://doi.org/10.1101/2020.08.05.20169136; this version posted August 6, 2020. The copyright holder for this preprint (which was not certified by peer review) is the author/funder, who has granted medRxiv a license to display the preprint in It is made available under a CC-BY-NC-ND 4.0 International license .

Table 2: EnrichR analysis of transcription factors (TFs) regulating differentially expressed genes in SLE-P vs SLE-NP monocytes

\begin{tabular}{|c|c|c|c|c|c|}
\hline TF & Panel & Genes & p-value & $\begin{array}{l}\text { Adj. p- } \\
\text { value }\end{array}$ & $\begin{array}{l}\text { Combined } \\
\text { Score }\end{array}$ \\
\hline RUNX1 & ChEA & $\begin{array}{l}\text { PRR5,MIDN,ARPC5L,SLC2A1,A } \\
\text { DARB1,SLC2A6,PTS,FAM216A, } \\
\text { SOCS3,LGALS1,ATG101,PIM1,E } \\
\text { 2F2,FFAR2,EPHB2,CDKN2D,ITG } \\
\text { A1,KREMEN1,SHISA5,EMP3,SA } \\
\text { P30,NINJ1,BCL3,BHLHE40,CD7,I } \\
\text { D3,MKRN3,BAX,HCST,LY6E }\end{array}$ & $1.00 \mathrm{E}-03$ & $1.24 \mathrm{E}-01$ & 12.194 \\
\hline SMC3 & ENCODE & $\begin{array}{l}\text { MIDN,CEBPB,RRBP1,SAT1,ASG } \\
\text { R1,SOCS3,ATG101,PIM1,RNF15 } \\
\text { 0,PIM2,CBX6,GADD45B,TREX1, } \\
\text { SPHK1,TRAPPC5,AP1AR,TOMM } \\
\text { 40L,CPED1,ABTB2,IL6,BBS10,A } \\
\text { RMC5,SCO2,DDAH2,BHLHE40,S } \\
\text { NAl1 }\end{array}$ & $5.00 \mathrm{E}-03$ & 2.61E-01 & 9.107 \\
\hline SP1 & ENCODE & $\begin{array}{l}\text { LYNX1,SDF2L1,NXT1,PET100,W } \\
\text { BP1,RFX2,UBALD2,RRBP1,TME } \\
\text { M97,WASH2P,TOMM40L,C12OR } \\
\text { F57,DRAP1,PIM1,ZSWIM4,NFKB } \\
\text { IB }\end{array}$ & 2.00E-02 & 7.00E-01 & 6.899 \\
\hline CEBPD & ENCODE & $\begin{array}{l}\text { MIDN,CEBPB,GADD45B,NCAPH } \\
\text { 2,RRBP1,ADARB1,C12ORF57,B } \\
\text { ST2,DDAH2,CCDC85B,ID1,BHL } \\
\text { HE40,E2F2,MDP1,ZBTB7A,PDLI } \\
\text { M7 }\end{array}$ & 2.70E-02 & 7.11E-01 & 6.128 \\
\hline SPI1 & ChEA & $\begin{array}{l}\text { CEBPB,CD82,BCL2A1,TRAPPC5 } \\
\text {,SHISA5,EMP3,GPR84,C12ORF5 } \\
\text { 7,BBS10,ARMC5,DHRS9,ADOR } \\
\text { A3,BHLHE40,KLF9,ID3,STAP1,PI } \\
\text { M3,CD14,NFKBIE,FCGR2B,HCS } \\
\text { T }\end{array}$ & $3.10 \mathrm{E}-02$ & 6.37E-01 & 5.415 \\
\hline ZBTB7A & ENCODE & $\begin{array}{l}\text { MIDN,CEBPB,NEXN,HSPB1,AD } \\
\text { M,RRBP1,ASGR1,FAM216A,C12 } \\
\text { ORF57,LGALS1,CCDC85B,RAV } \\
\text { ER2,HCFC1R1,PIM1,PIM3,CKB, } \\
\text { ZSWIM4,ZBTB7A,ZNF322,PDLIM } \\
\text { 7,RAB11FIP5,HES4,CDKN2D,GA } \\
\text { DD45B,SPHK1,TRAPPC5,DUSP } \\
\text { 8,SPATA2L,ITPKC,TRAF4,DDAH } \\
\text { 2,ID1,BCL3,BHLHE40,SNAI1,AG } \\
\text { RN,NFKBIE,BLVRA }\end{array}$ & $3.10 \mathrm{E}-02$ & 5.38E-01 & 4.721 \\
\hline CTCF & ENCODE & $\begin{array}{l}\text { MIDN,CEBPB,NDUFB7,RRBP1,S } \\
\text { AT1,ASGR1,SOCS3,ATG101,CC } \\
\text { DC85B,PIM1,RNF150,PIM2,MDP } \\
\text { 1,PDLIM7,KCNJ2,SDF2L1,GADD } \\
\text { 45B,TREX1,SPHK1,TRAPPC5,A } \\
\text { P1AR,TOMM40L,SPATA2L,CPE } \\
\text { D1,ABTB2,IL6,BBS10,ARMC5,S } \\
\text { CO2,DDAH2,BHLHE40,SNAI1 }\end{array}$ & 3.40E-02 & 5.01E-01 & 4.735 \\
\hline
\end{tabular}

Table of transcription factors and consensus target genes using ENCODE and ChEA. TF refers to the transcription factor identifier. Panel refers to either ENCODE or ChEA repositories used to enrich term. Genes includes all genes from input seed gene list targeted by specific transcription factor. P-value is Fisher's exact test statistic. Adj. p-value refers to the adjusted p-value using Benjamini-Hochberg 
medRxiv preprint doi: https://doi.org/10.1101/2020.08.05.20169136; this version posted August 6, 2020. The copyright holder for this preprint (which was not certified by peer review) is the author/funder, who has granted medRxiv a license to display the preprint in It is made available under a CC-BY-NC-ND 4.0 International license

correction for multiple hypothesis testing. Combined score refers to the p-value and z-score (deviation from expected rank) calculated by multiplying the two values (combined score $=$ natural $\log (p$-value) multiplied by z-score).

Table 3: Differentially expressed genes in SLE-P monocytes in the IFNab signalling pathway

\begin{tabular}{|l|l|r|r|}
\hline Genes & Annotation & p-value & $\begin{array}{l}\text { Fold } \\
\text { change }\end{array}$ \\
\hline BST2 & bone marrow stromal cell antigen 2 & $3.00 \mathrm{E}-04$ & -1.96 \\
\hline ISG15 & ISG15 ubiquitin like modifier & $1.00 \mathrm{E}-03$ & -1.75 \\
\hline IFITM2 & interferon induced transmembrane protein 2 & $1.00 \mathrm{E}-03$ & -3.79 \\
\hline IRF7 & interferon regulatory factor 7 & $2.00 \mathrm{E}-03$ & -1.96 \\
\hline SOCS3 & suppressor of cytokine signaling 3 & $2.00 \mathrm{E}-03$ & -2.35 \\
\hline IFITM3 & interferon induced transmembrane protein 3 & $2.00 \mathrm{E}-03$ & -2.77 \\
\hline IFITM1 & interferon induced transmembrane protein 1 & $3.00 \mathrm{E}-03$ & -3.00 \\
\hline IFI6 & interferon alpha inducible protein 6 & $5.00 \mathrm{E}-03$ & -1.76 \\
\hline IFI35 & interferon induced protein 35 & $5.00 \mathrm{E}-03$ & -2.99 \\
\hline
\end{tabular}

Table of differential gene expression values for genes enriched in IFNab signalling pathway (hsa909733) in SLE-P compared to SLE-NP. Fold change refers to the direction of change in gene expression with negative numbers depicting downregulated gene expression in linear format. 
medRxiv preprint doi: https://doi.org/10.1101/2020.08.05.20169136; this version posted August 6, 2020. The copyright holder for this preprint (which was not certified by peer review) is the author/funder, who has granted medRxiv a license to display the preprint in It is made available under a CC-BY-NC-ND 4.0 International license .

Table 4. Genes differentially expressed in SLE-P monocytes and symptomatic plaque macrophages identified by scRNA-seq analysis (Fernandez et al., 2019)

\begin{tabular}{|l|l|r|r|}
\hline Genes & Annotation & p-value & $\begin{array}{l}\text { Fold } \\
\text { change }\end{array}$ \\
\hline ZBTB16 & zinc finger and BTB domain containing 16 & $4.91 \mathrm{E}-06$ & 7.51 \\
\hline PIM3 & Pim-3 proto-oncogene, serine/threonine kinase & $1.70 \mathrm{E}-04$ & -2.13 \\
\hline LPL & lipoprotein lipase & $4.23 \mathrm{E}-04$ & 3.18 \\
\hline IFITM2 & interferon induced transmembrane protein 2 & $8.30 \mathrm{E}-04$ & -1.75 \\
\hline BCL3 & BCL3 transcription coactivator & $8.61 \mathrm{E}-04$ & -1.83 \\
\hline PTX3 & pentraxin 3 & $7.70 \mathrm{E}-04$ & -1.97 \\
\hline BHLHE40 & basic helix-loop-helix family member e40 & $9.75 \mathrm{E}-04$ & -1.74 \\
\hline SNHG15 & small nucleolar RNA host gene 15 & $9.97 \mathrm{E}-04$ & -1.91 \\
\hline PET100 & PET100 cytochrome c oxidase chaperone & $1.19 \mathrm{E}-03$ & -1.62 \\
\hline EMP3 & epithelial membrane protein 3 & $1.73 \mathrm{E}-03$ & -1.73 \\
\hline ATF3 & activating transcription factor 3 & $2.01 \mathrm{E}-03$ & -2.19 \\
\hline SOCS3 & suppressor of cytokine signaling 3 & $2.01 \mathrm{E}-03$ & -2.35 \\
\hline CDK11A & cyclin dependent kinase 11A & $2.65 \mathrm{E}-03$ & -1.51 \\
\hline CEBPB & CCAAT enhancer binding protein beta & $3.24 \mathrm{E}-03$ & -1.82 \\
\hline S100A9 & S100 calcium binding protein A9 & $3.81 \mathrm{E}-03$ & -1.68 \\
\hline NDUFA3 & NADH:ubiquinone oxidoreductase subunit A3 & $4.23 \mathrm{E}-03$ & -1.63 \\
\hline TSTD1 & thiosulfate sulfurtransferase like domain containing 1 & $4.23 \mathrm{E}-03$ & -1.66 \\
\hline HCST & hematopoietic cell signal transducer & $5.16 \mathrm{E}-03$ & -1.64 \\
\hline CRIP2 & cysteine rich protein 2 & $5.31 \mathrm{E}-03$ & -2.48 \\
\hline MIR3945HG & MIR3945 host gene & $5.67 \mathrm{E}-03$ & -2.06 \\
\hline CD7 & CD7 molecule & $6.37 \mathrm{E}-03$ & -1.57 \\
\hline MIDN & midnolin & $7.23 \mathrm{E}-03$ & -1.62 \\
\hline FCGR2B & Fc fragment of IgG receptor Ilb & $7.53 \mathrm{E}-03$ & 1.76 \\
\hline BCL2A1 & BCL2 related protein A1 & $8.31 \mathrm{E}-03$ & -1.91 \\
\hline KLF9 & Kruppel like factor 9 & $8.34 \mathrm{E}-03$ & 1.90 \\
\hline PSMB9 & proteasome 20S subunit beta 9 & $8.89 \mathrm{E}-03$ & -1.68 \\
\hline CDKN1A & cyclin dependent kinase inhibitor 1A & $9.88 \mathrm{E}-03$ & -1.72 \\
\hline & & & \\
\hline
\end{tabular}

Fold change as in Table 3. Genes in bold also conserved in laser capture microdissection symptomatic plaque macrophage expression list. 
medRxiv preprint doi: https://doi.org/10.1101/2020.08.05.20169136; this version posted August 6, 2020. The copyright holder for this preprint (which was not certified by peer review) is the author/funder, who has granted medRxiv a license to display the preprint in It is made available under a CC-BY-NC-ND 4.0 International license.

Table 5. Genes differentially expressed in SLE-P monocytes and laser capture microdissection symptomatic plaque macrophages (Chai et al., 2018)

\begin{tabular}{|l|l|r|r|}
\hline Genes & Annotation & p-value & $\begin{array}{l}\text { Fold } \\
\text { change }\end{array}$ \\
\hline ISG15 & ISG15 ubiquitin like modifier & $7.09 \mathrm{E}-04$ & -3.79 \\
\hline SAP30 & Sin3A associated protein 30 & $1.17 \mathrm{E}-03$ & 2.80 \\
\hline P2RY1 & purinergic receptor P2Y1 & $1.29 \mathrm{E}-03$ & 3.03 \\
\hline ASGR1 & asialoglycoprotein receptor 1 & $1.90 \mathrm{E}-03$ & -1.59 \\
\hline S100A8 & S100 calcium binding protein A8 & $2.37 \mathrm{E}-03$ & -1.77 \\
\hline IL4I1 & interleukin 4 induced 1 & $3.45 \mathrm{E}-03$ & -1.85 \\
\hline S100A9 & S100 calcium binding protein A9 & $3.81 \mathrm{E}-03$ & -1.68 \\
\hline IFI6 & interferon alpha inducible protein 6 & $4.51 \mathrm{E}-03$ & -2.99 \\
\hline ADM & adrenomedullin & $4.83 \mathrm{E}-03$ & -1.61 \\
\hline BCL2A1 & BCL2 related protein A1 & $8.31 \mathrm{E}-03$ & -1.91 \\
\hline KCNJ2 & $\begin{array}{l}\text { potassium inwardly rectifying channel subfamily J } \\
\text { member 2 }\end{array}$ & $9.35 \mathrm{E}-03$ & 2.04 \\
\hline
\end{tabular}

Fold change as in Table 3. Genes in bold also conserved in scRNA-seq symptomatic plaque macrophage expression list. 
medRxiv preprint doi: https://doi.org/10.1101/2020.08.05.20169136; this version posted August 6, 2020. The copyright holder for this preprint (which was not certified by peer review) is the author/funder, who has granted medRxiv a license to display the preprint in perpetuity.

It is made available under a CC-BY-NC-ND 4.0 International license .

Table 6. Overlapping pathways and enrichment across SLE-P monocytes, scRNA-seq (Fernandez et al., 2019) and laser capture microdissection (Chai et al., 2018) symptomatic plaque macrophages

\begin{tabular}{|c|c|c|c|c|c|}
\hline Pathway & $\begin{array}{l}\text { Pathway } \\
\text { ID }\end{array}$ & Genes & $\begin{array}{l}\log 10 \\
\text { (p) }\end{array}$ & $\begin{array}{l}\log 10 \\
\text { (q) }\end{array}$ & ES \\
\hline $\begin{array}{l}\text { IL12 } 2 \\
\text { Pathway/ } \\
\text { Downstream } \\
\text { TCR signalling }\end{array}$ & M54 & $\begin{array}{l}\text { CD3D,CD3E,CD3G,FOS,GZMA,HL } \\
\text { A-DRA,HLA- } \\
\text { DRB1,HLX,IL1B,IL2RA,LCK,GADD } \\
\text { 45B,NFKB1,MAP2K3,CCL3,CCL4, } \\
\text { STAT1,STAT3,HLA-DPA1,HLA- } \\
\text { DPB1,HLA- } \\
\text { DRB5,NFKBIA,PSMA2,PSMB1,PS } \\
\text { MB9,PSME2,SKP1,UBA52,UBB,E } \\
\text { VL,CD80,CDC42,MAP3K8,PPP2C } \\
\text { A,PPP2R5C,MAP3K14,PRR5,IRF1 } \\
\text {,JUN,RHOB,PTK2B,ITGA1,ITGA5,I } \\
\text { TGA7,RAP1B,RGS1,RACK1,PRKC } \\
\text { B,IL7R,JAK3 }\end{array}$ & -11.896 & -9.578 & 8.61 \\
\hline Apoptosis & hsa04210 & $\begin{array}{l}\text { ACTG1,BAX,BCL2A1,CTSC,CTSH, } \\
\text { CTSK,CTSL,CTSZ,GADD45A,FOS } \\
\text {,JUN,LMNA,MCL1,GADD45B,NFK } \\
\text { B1,NFKBIA,TNF,TUBA4A,TUBA1A } \\
\text {,MAP3K14,CYCS }\end{array}$ & -8.224 & -6.264 & 3.35 \\
\hline $\begin{array}{l}\text { MAPK family } \\
\text { signaling } \\
\text { cascade }\end{array}$ & $\begin{array}{l}\text { R-HSA- } \\
5683057\end{array}$ & $\begin{array}{l}\text { ACTG1,AREG,CDC42,CSF2RA,HB } \\
\text { EGF,DUSP1,DUSP2,DUSP8,ERE } \\
\text { G,FOXO3,FLT3,FN1,HSPB1,DNAJ } \\
\text { B1,IL2RA,IL6,JAK1,JAK3,JUN,PPP } \\
\text { 2CA,PPP2R5C,PRKACB,PSMA2,P } \\
\text { SMA6,PSMB1,PSMB9,PSMD11,P } \\
\text { SME2,RAP1B,UBA52,UBB,YWHA } \\
\text { B,DUSP10,NFKB1,NFKBIA,NFKBI } \\
\text { B,NFKBIE,PRKCB,REL,SKP1,CAL } \\
\text { R,CD14,CTSL,CYBA,HLA-C,HLA- } \\
\text { E,HLA- } \\
\text { F,MRC1,TLR2,VAMP8,APP,MAP3 } \\
\text { K8,IL1B,IL1RN,IL1R2,PELI1,CASP } \\
\text { 1,STAT3,IL18BP,PPIA,CD79B,ZFH } \\
\text { X3,CDKN1A,HES1,NOTCH1,SPP1 } \\
\text {,HSPA1B,ZFP36,MAPKAPK2,PAB } \\
\text { PC1,BAX,E2F1,GSN,LMNA,PLEC, } \\
\text { VIM,YWHAH,YWHAQ,CYCS,TLE5, } \\
\text { LTB,TNF,MAP3K14,TNFSF15,TNF } \\
\text { SF13B,TUBA4A,TUBA1A,TUBB6,C } \\
\text { DKN1C,CDKN2D,E2F2,E2F3,MCM } \\
\text { 10,CDK11B,PHLDA1,CDK11A,CLE } \\
\text { C10A,MUC5B,ITGA5,STAT1,ELOC } \\
\text {,FOS,AP1S1,LCK,ABL2,MYO9B,R } \\
\text { PS4Y1,NRP1,EIF4A3,EVL,SRGAP } \\
\text { 1,ALCAM,RHOB,CACNB4,EPHB2,I } \\
\text { TGA1,SDC2,PDLIM7,PLXNC1,MY } \\
\text { L12A,TREM2,AGRN,ADAM17,ZBT } \\
\text { B16,SOCS3,ERAP2,EGR1,SNAI1, } \\
\text { CBX6,LAMTOR1,RAC2,NCOR2,H2 } \\
\text { AJ,USP15,INO80B,RHNO1,COMM } \\
\text { D6 }\end{array}$ & -8.979 & -6.944 & 3.31 \\
\hline $\begin{array}{l}\text { Toll-like } \\
\text { receptor } \\
\text { signalling } \\
\text { pathway }\end{array}$ & hsa04620 & 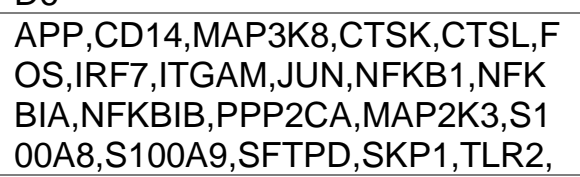 & -14.337 & -11.845 & 7.24 \\
\hline
\end{tabular}


medRxiv preprint doi: https://doi.org/10.1101/2020.08.05.20169136; this version posted August 6, 2020. The copyright holder for this preprint (which was not certified by peer review) is the author/funder, who has granted medRxiv a license to display the preprint in It is made available under a CC-BY-NC-ND 4.0 International license .

\begin{tabular}{|c|c|c|c|c|c|}
\hline & & $\begin{array}{l}\text { UBA52,UBB,MAPKAPK2,LY86,PE } \\
\text { LI1,LRRFIP1,TREX1,STING1,TNF } \\
\text { AIP3,ISG15,DHX58 }\end{array}$ & & & \\
\hline $\begin{array}{l}\text { TNF signalling } \\
\text { pathway/ } \\
\text { IL-17 } \\
\text { signalling/ T } \\
\text { cell receptor } \\
\text { signalling }\end{array}$ & hsa04668 & $\begin{array}{l}\text { BCL3,CEBPB,FOS,CXCL1,CXCL2, } \\
\text { CXCL3,ICAM1,IL1B,JUN,JUNB,M } \\
\text { MP14,NFKB1,NFKBIA,MAP2K3,PT } \\
\text { GS2,CCL5,CCL20,CXCL5,TNF,TN } \\
\text { FAIP3,SOCS3,FOSB,IL6,CXCL8,C } \\
\text { XCL10,JUND,S100A8,S100A9,TR } \\
\text { AF4,MUC5B,C1QC,CALR,CD3D,C } \\
\text { D3E,CD3G,IFNGR2,IL10,PPP2CA, } \\
\text { CCL3,TLR2,CCL3L3,CASP1,CYBA } \\
\text {,GBP2,JAK1,NAIP,TXN,NAMPT,TX } \\
\text { NIP,GABARAP,NLRP3,STING1,AC } \\
\text { P5,CTSK,FCGR2B,FOSL2,LCK,TR } \\
\text { EM2,IRF1,ITGA5,ITGAM,CDC42,M } \\
\text { AP3K8,NFKBIB,NFKBIE,MAP3K14 }\end{array}$ & -14.408 & -11.547 & 6.62 \\
\hline $\begin{array}{l}\text { Neutrophil } \\
\text { degranulation }\end{array}$ & $\begin{array}{l}\text { R-HSA- } \\
6798695\end{array}$ & $\begin{array}{l}\text { ANPEP,ANXA2,APRT,RHOG,BST } \\
\text { 1,BST2,C5AR1,CAT,CD14,CD33,A } \\
\text { DGRE5,CTSC,CNN2,CR1,CST3,C } \\
\text { TSH,CTSZ,CYBA,CD55,FABP5,FC } \\
\text { N1,GLB1,CXCL1,GSN,HLA- } \\
\text { C,HSPA1B,IDH1,ITGAM,LYZ,MGS } \\
\text { T1,MIF,MNDA,NFKB1,PNP,OLR1, } \\
\text { PAFAH1B2,SERPINA1,PKM,PLAU } \\
\text { R,PPIA,PSMA2,PSMB1,PSMD11,P } \\
\text { TX3,RAP1B,RNASE2,RNASE3,S1 } \\
\text { 00A8,S100A9,SLC2A3,SRP14,TIM } \\
\text { P2,TLR2,TNFAIP6,VAMP8,VAPA, } \\
\text { GMFG,ATP6AP2,FGL2,CKAP4,GLI } \\
\text { PR1,COTL1,GCA,PLAC8,GPR84,L } \\
\text { AMTOR1,RETN,CYSTM1,LRG1,A } \\
\text { RL8A,CLEC12A,MCEMP1,STING1 } \\
\text {,TBC1D10C,SIGLEC14 }\end{array}$ & -28.718 & -25.303 & 4.71 \\
\hline $\begin{array}{l}\text { Adaptive } \\
\text { Immune } \\
\text { System }\end{array}$ & $\begin{array}{l}\text { R-HSA- } \\
1280218\end{array}$ & $\begin{array}{l}\text { CALR,CD3D,CD3E,CD3G,CD14,C } \\
\text { D80,CD33,CD74,CD79B,CDC42,C } \\
\text { TSC,AP1S1,MAP3K8,CTSH,CTSK, } \\
\text { CTSL,CYBA,FCGR2B,HLA-C,HLA- } \\
\text { DMB,HLA-DOA,HLA-DPA1,HLA- } \\
\text { DPB1,HLA-DRA,HLA-DRB1,HLA- } \\
\text { DRB5,HLA-E,HLA- } \\
\text { F,ICAM1,KLRB1,LCK,CD99,MRC1, } \\
\text { NFKB1,NFKBIA,NFKBIB,NFKBIE,P } \\
\text { PIA,PPP2CA,PPP2R5C,PRKACB, } \\
\text { PRKCB,PSMA2,PSMA6,PSMB1,P } \\
\text { SMB9,PSMD11,PSME2,NECTIN2, } \\
\text { RAP1B,REL,SFTPD,SKP1,ELOC,T } \\
\text { LR2,TUBA4A,UBA52,UBB,YWHAB } \\
\text {,ZBTB16,TUBA1A,IFITM1,VAMP8, } \\
\text { MAP3K14,SOCS3,KLRG1,IFI30,U } \\
\text { BE2E3,HCST,EVL,TREM2,TREM1, } \\
\text { PRR5,ERAP2,TUBB6,JAML,RNF1 } \\
\text { 44B }\end{array}$ & -17.579 & -14.863 & 3.05 \\
\hline $\begin{array}{l}\text { Interferon } \\
\text { Signalling }\end{array}$ & $\begin{array}{l}\text { R-HSA- } \\
913531\end{array}$ & $\begin{array}{l}\text { BST2,EGR1,EIF4E,FLNB,IFI6,GBP } \\
\text { 2,HLA-C,HLA-DPA1,HLA- } \\
\text { DPB1,HLA-DRA,HLA-DRB1,HLA- } \\
\text { DRB5,HLA-E,HLA- } \\
\text { F,ICAM1,IFI27,IFI35,IFIT2,IFIT1,IFI } \\
\text { T3,IFNGR1,IFNGR2,IRF1,IRF7,JA } \\
\text { K1,MT2A,MX1,OAS2,STAT1,UBA5 } \\
\text { 2,UBB,IFITM1,SOCS3,ISG15,EIF4 } \\
\text { A3,IFITM3,IFI30,IFITM2,SAMHD1, } \\
\text { RSAD2 }\end{array}$ & -19.434 & -16.417 & 6.02 \\
\hline
\end{tabular}


medRxiv preprint doi: https://doi.org/10.1101/2020.08.05.20169136; this version posted August 6, 2020. The copyright holder for this preprint (which was not certified by peer review) is the author/funder, who has granted medRxiv a license to display the preprint in perpetuity.

It is made available under a CC-BY-NC-ND 4.0 International license

\begin{tabular}{|c|c|c|c|c|c|}
\hline $\begin{array}{l}\text { Signalling by } \\
\text { Interleukins/ } \\
\text { Interleukin-4 } \\
\text { and } \\
\text { interleukin-13/ } \\
\text { JAK-STAT } \\
\text { pathway }\end{array}$ & $\begin{array}{l}\text { R-HSA- } \\
449147\end{array}$ & $\begin{array}{l}\text { ANXA1,ANXA2,APP,BCL6,CASP1, } \\
\text { CD80,CDC42,CDKN1A,CNN2,MAP } \\
\text { 3K8,CSF2RA,CSF3R,PTK2B,FOX } \\
\text { O3,FN1,FOS,CXCL1,CXCL2,ICAM } \\
\text { 1,IL1B,IL1RN,IL2RA,IL6,IL7R,CXC } \\
\text { L8,IL10,IL13RA1,CXCL10,ITGAM,J } \\
\text { AK1,JAK3,JUN,JUNB,LCK,LGALS } \\
\text { 9,MAOA,MCL1,MIF,NFKB1,NFKBI } \\
\text { A,NFKBIB,OSM,PIM1,PPIA,PPP2C } \\
\text { A,MAP2K3,PSMA2,PSMA6,PSMB1 } \\
\text {,PSMB9,PSMD11,PSME2,PTGS2, } \\
\text { RAP1B,CCL3,CCL4,CCL5,CCL20, } \\
\text { SKP1,SOD2,STAT1,STAT3,STXBP } \\
\text { 2,TALDO1,TIMP1,TNF,UBA52,UB } \\
\text { B,VIM,IL1R2,SOCS3,IL32,MAPKA } \\
\text { PK2,IL18BP,PELI1,CCL4L1,CCL3L } \\
\text { 3,IFNGR1,IFNGR2 }\end{array}$ & -31.493 & -27.777 & 5.03 \\
\hline $\begin{array}{l}\text { Hematopoietic } \\
\text { cell lineage/ } \\
\text { Rheumatoid } \\
\text { Arthritis/ Cell } \\
\text { adhesion } \\
\text { molecules }\end{array}$ & hsa04640 & $\begin{array}{l}\text { ANPEP,CD1E,CD2,CD3D,CD3E,C } \\
\text { D3G,CD7,CD9,CD14,CD33,CR1,C } \\
\text { SF2RA,CSF3R,CD55,FLT3,HLA- } \\
\text { DMB,HLA-DOA,HLA-DPA1,HLA- } \\
\text { DPB1,HLA-DRA,HLA-DRB1,HLA- } \\
\text { DRB5,IL1B,IL2RA,IL6,IL7R,ITGA1,I } \\
\text { TGA5,ITGAM,TNF,IL1R2,ACP5,AT } \\
\text { P6AP1,CD80,CTSK,CTSL,FOS,CX } \\
\text { CL1,ICAM1,CXCL8,JUN,LTB,CCL3 } \\
\text {,CCL5,CCL20,CXCL5,TLR2,TNFS } \\
\text { F13B,CCL3L3,CYBA,IFNGR1,IFN } \\
\text { GR2,IL10,JAK1,NFKB1,NFKBIA,N } \\
\text { FKBIB,PRKCB,PTGS2,STAT1,ACT } \\
\text { G1,CASP1,HSPA1B,DNAJB1,CXC } \\
\text { L10,IRF7,MX1,OAS2,MAP2K3,SO } \\
\text { CS3,NXT1,CYCS,RSAD2,NLRP3, } \\
\text { CD74,EEF1D,HLA-C,HLA-E,HLA- } \\
\text { F,IFIT1,NECTIN2,SKP1,ALYREF,J } \\
\text { AK3,LCK,NFKBIE,STAT3,NOTCH1 } \\
\text {,ATF3,BAX,CALR,CDKN1A,E2F1,E } \\
\text { 2F2,E2F3,EGR1,PRKACB,SLC2A1 } \\
\text {,ZFP36,NRP1,MAP3K14,FCGR2B, } \\
\text { MRC1,MSR1,OLR1,SFTPD,THBS1 } \\
\text {,TUBA4A,TUBA1A,CORO1A,TUBB } \\
\text { 6,CEBPB,PLK3,LSP1,SPHK1,ABL } \\
\text { 2,RAC2,PPIF,TNFAIP3,RACK1,PS } \\
\text { ME2,IFI30,C1QCC,C5AR1,KRT10,R } \\
\text { NASE3,ALCAM,CD99,SDC2,SDC4 } \\
\text {,CTSC,AP1S1,CTSH,SSB,H2AJ }\end{array}$ & -21.659 & -18.420 & 9.63 \\
\hline $\begin{array}{l}\text { Toll-like } \\
\text { Receptor } \\
\text { Cascades }\end{array}$ & $\begin{array}{l}\text { R-HSA- } \\
168898\end{array}$ & $\begin{array}{l}\text { CD14,CD80,MAP3K8,CTSK,FOS,I } \\
\text { L1B,IL6,CXCL8,CXCL10,IRF7,JUN } \\
\text {,CXCL9,NFKB1,NFKBIA,MAP2K3, } \\
\text { CCL3,CCL4,CCL5,SPP1,STAT1,TL } \\
\text { R2,TNF,CCL4L2,CCL4L1,CCL3L3, } \\
\text { ACTG1,RHOG,CASP1,CDC42,FLN } \\
\text { B,CXCL1,CXCL2,CXCL3,IFNGR1,I } \\
\text { FNGR2,ARPC5L,BCL2A1,ICAM1,L } \\
\text { CK,LTB,GADD45B,PRKCB,PTGS2 } \\
\text {,CCL13,TNFAIP3,MAP3K14,TNFS } \\
\text { F13B,NFKBIB,TREX1,STING1 }\end{array}$ & -9.289 & -7.217 & 4.58 \\
\hline $\begin{array}{l}\text { Interleukin-10 } \\
\text { signalling }\end{array}$ & $\begin{array}{l}\text { R-HSA- } \\
6783783\end{array}$ & $\begin{array}{l}\text { CD80,CXCL1,CXCL2,ICAM1,IL1B,I } \\
\text { L1RN,IL6,CXCL8,IL10,CXCL10,JA } \\
\text { K1,PTGS2,CCL3,CCL4,CCL5,CCL } \\
\text { 20,STAT3,TIMP1,TNF,IL1R2,CCL4 } \\
\text { L1,CCL3L3,A2M,ANXA1,ANXA2,A } \\
\text { NXA6,AREG,C1QC,CTSC,CST3,C }\end{array}$ & -19.825 & -16.711 & 14.10 \\
\hline
\end{tabular}


medRxiv preprint doi: https://doi.org/10.1101/2020.08.05.20169136; this version posted August 6, 2020. The copyright holder for this preprint (which was not certified by peer review) is the author/funder, who has granted medRxiv a license to display the preprint in perpetuity.

It is made available under a CC-BY-NC-ND 4.0 International license .

\begin{tabular}{|c|c|c|c|c|c|}
\hline & & $\begin{array}{l}\text { TSH,CTSK,CTSL,CTSZ,HBEGF,E } \\
\text { REG,FCN1,CXCL3,LGALS1,LGAL } \\
\text { S2,LGALS9,LTB,CXCL9,MMP14,M } \\
\text { MP19,OSM,SERPINF1,SERPINA1, } \\
\text { HTRA1,S100A4,S100A6,S100A8,S } \\
\text { 100A9,S100A10,CCL8,CCL13,CXC } \\
\text { L5,SDC2,SDC4,SFTPD,ADAM17,T } \\
\text { IMP2,CST7,ADAM9,CCL4L2,TNFS } \\
\text { F15,PLXNC1,FSTL3,CLEC10A,TN } \\
\text { FSF13B,GREM1,ADAMDEC1,FAM } \\
\text { 20A,SULF2,PDGFC,PIK3IP1,CLEC } \\
\text { 12A,MUC5B,CDC42,PTK2B,FOXO } \\
\text { 3,JAK3,NFKB1,NFKBIA,NFKBIB,P } \\
\text { RKACB,PRKCB,RAC2,RAP1B,STA } \\
\text { T1,CSF2RA,CSF3R,FLT3,IFNGR1, } \\
\text { IFNGR2,IL2RA,IL7R,IL13RA1,TNF } \\
\text { RSF21,ADORA3,APP,C5AR1,CMK } \\
\text { LR1,GPR183,GPR35,FFAR2,P2RY } \\
\text { 1,GPR65,HCAR3,UTS2,GHRL,P2R } \\
\text { Y13,P2RY12,HCAR2,LPL,PDE4B, } \\
\text { PPP2CA,RGS1,DHRS9,METAP2, } \\
\text { GPSM3,AGRN,ADM,ADGRE5,CD5 } \\
5\end{array}$ & & & \\
\hline $\begin{array}{l}\text { IL6 } 7 \text { Pathway/ } \\
\text { IL2 } 1 \text { Pathway }\end{array}$ & M183 & $\begin{array}{l}\text { A2M,CEBPB,FOS,IL6,IRF1,JAK1,J } \\
\text { UN,JUNB,MCL1,PTPRE,STAT1,ST } \\
\text { AT3,TIMP1,SOCS3,PTK2B,IL2RA, } \\
\text { JAK3,LCK,PRKCB,MAPKAPK2,CA } \\
\text { SP1,IFNGR1,IL1B,RAP1B,CSF2R } \\
\text { A,LGALS9,IFNGR2,OSM,E2F1,FO } \\
\text { XO3,NFKB1,TNF,SDC2,IL7R }\end{array}$ & -9.661 & -7.535 & 8.97 \\
\hline $\begin{array}{l}\text { Hepatitis B/ } \\
\text { Pathways in } \\
\text { cancer }\end{array}$ & hsa05161 & $\begin{array}{l}\text { ATP6AP1,BAX,CDKN1A,E2F1,E2F } \\
\text { 2,E2F3,PTK2B,FOS,IL6,CXCL8,IR } \\
\text { F7,JAK1,JUN,NFKB1,NFKBIA,PRK } \\
\text { CB,STAT1,STAT3,TLR2,TNF,YWH } \\
\text { AB,YWHAQ,CYCS,BRCA2,CDC42, } \\
\text { CKS2,CSF2RA,CSF3R,FLT3,FN1, } \\
\text { PRKACB,PTGS2,RAC2,SLC2A1,E } \\
\text { LOC,ZBTB16,TRAF4 }\end{array}$ & -9.372 & -7.273 & 4.81 \\
\hline $\begin{array}{l}\text { Cellular } \\
\text { response to } \\
\text { external } \\
\text { stimuli/ cellular } \\
\text { senescence }\end{array}$ & $\begin{array}{l}\text { R-HSA- } \\
8953897\end{array}$ & $\begin{array}{l}\text { ATF3,CAT,CDKN1A,CEBPB,CYBA } \\
\text {,E2F3,FOS,GPX3,DNAJA1,HSPA1 } \\
\text { B,DNAJB1,CXCL8,JUN,MT1E,MT1 } \\
\text { F,MT1X,MT2A,NFKB1,MAP2K3,PS } \\
\text { MA2,PSMB1,PSMB9,PSME2,SOD } \\
\text { 2,STAT3,ELOC,PRDX2,TUBA4A,T } \\
\text { XN,UBA52,UBB,MAPKAPK2,DNAJ } \\
\text { B6,HSPH1,KDM6B,PPP1R15A,CY } \\
\text { CS,LAMTOR1,TUBB6,CDKN2D,E2 } \\
\text { F1,E2F2,ID1,IL6,CBX6,H2AJ }\end{array}$ & -9.811 & -7.614 & 3.23 \\
\hline
\end{tabular}

ES: Enrichment score. Nomenclature and analysis as in Table 1. 
medRxiv preprint doi: https://doi.org/10.1101/2020.08.05.20169136; this version posted August 6, 2020. The copyright holder for this preprint (which was not certified by peer review) is the author/funder, who has granted medRxiv a license to display the preprint in It is made available under a CC-BY-NC-ND 4.0 International license .

Table 7: Differentially expressed genes in SLE-P monocytes DIAMOnD seed set

\begin{tabular}{|c|c|c|c|}
\hline Seeds & Annotation & p-value & $\begin{array}{l}\text { Fold } \\
\text { change }\end{array}$ \\
\hline ZNF33B & zinc finger protein 33B & 4.00E-07 & 1.71 \\
\hline ZBTB16 & zinc finger and BTB domain containing 16 & $5.00 \mathrm{E}-06$ & 7.51 \\
\hline ZNF302 & zinc finger protein 302 & 3.00E-06 & 1.72 \\
\hline FFAR2 & free fatty acid receptor 2 & $4.00 \mathrm{E}-06$ & -3.79 \\
\hline U2AF1L4* $^{*}$ & U2 small nuclear RNA auxiliary factor 1 like 4 & 1.00E-05 & -1.73 \\
\hline TMIGD3 & $\begin{array}{l}\text { transmembrane and immunoglobulin domain } \\
\text { containing } 3\end{array}$ & 3.00E-05 & 4.05 \\
\hline WBP1 & WW domain binding protein 1 & 4.00E-05 & -2.75 \\
\hline ADORA3 & adenosine $A 3$ receptor & 4.00E-05 & 3.99 \\
\hline ADARB1 & adenosine deaminase RNA specific B1 & 8.00E-05 & -1.79 \\
\hline IL6 & interleukin 6 & 8.00E-05 & -5.38 \\
\hline SCO2 & synthesis of cytochrome $\mathrm{C}$ oxidase 2 & 9.00E-05 & -2.51 \\
\hline MRC1 & mannose receptor C-type 1 & 1.00E-04 & 2.77 \\
\hline FLT3 & fms related receptor tyrosine kinase 3 & 1.00E-04 & 4.00 \\
\hline RNF150 & ring finger protein 150 & 1.00E-04 & 61.26 \\
\hline IL13RA1 & interleukin 13 receptor subunit alpha 1 & 2.00E-04 & 1.52 \\
\hline DRAP1 & DR1 associated protein 1 & 2.00E-04 & -1.82 \\
\hline DDAH2 & dimethylarginine dimethylaminohydrolase 2 & 2.00E-04 & -1.87 \\
\hline ABTB2 & ankyrin repeat and BTB domain containing 2 & $2.00 \mathrm{E}-04$ & -2.09 \\
\hline PIM3 & Pim-3 proto-oncogene, serine/threonine kinase & $2.00 \mathrm{E}-04$ & -2.13 \\
\hline SPHK1 & sphingosine kinase 1 & 1.00E-04 & -2.34 \\
\hline HLA-DOA & major histocompatibility complex, class II, DO alpha & 2.00E-04 & 2.36 \\
\hline GAPT & GRB2 binding adaptor protein, transmembrane & 2.00E-04 & 1.75 \\
\hline CD14 & CD14 molecule & 2.00E-04 & -1.57 \\
\hline $\mathrm{HLX}$ & H2.0 like homeobox & 2.00E-04 & -1.79 \\
\hline CCDC122 & coiled-coil domain containing 122 & 2.00E-04 & 3.77 \\
\hline TYMP & thymidine phosphorylase & 3.00E-04 & -2.12 \\
\hline ALOX15B & arachidonate 15-lipoxygenase type B & 4.00E-04 & 3.47 \\
\hline LPL & lipoprotein lipase & 4.00E-04 & 3.18 \\
\hline FKBP5 & FKBP prolyl isomerase 5 & 4.00E-04 & 2.66 \\
\hline P2RY12 & purinergic receptor P2Y12 & 4.00E-04 & 2.65 \\
\hline RRBP1 & ribosome binding protein 1 & $4.00 \mathrm{E}-04$ & -1.60 \\
\hline SLC2A6 & solute carrier family 2 member 6 & $4.00 \mathrm{E}-04$ & -1.77 \\
\hline GPR35 & G protein-coupled receptor 35 & 4.00E-04 & -1.79 \\
\hline NFKBIE & NFKB inhibitor epsilon & 4.00E-04 & -1.86 \\
\hline BST2 & bone marrow stromal cell antigen 2 & $3.00 \mathrm{E}-04$ & -1.96 \\
\hline PLEKHN1 & pleckstrin homology domain containing N1 & $3.00 \mathrm{E}-04$ & -1.97 \\
\hline E2F2 & E2F transcription factor 2 & $4.00 \mathrm{E}-04$ & -2.04 \\
\hline ITGA7 & integrin subunit alpha 7 & $3.00 \mathrm{E}-04$ & -2.46 \\
\hline CKB & creatine kinase $\mathrm{B}$ & 3.00E-04 & -3.09 \\
\hline TPST1 & tyrosylprotein sulfotransferase 1 & 7.00E-04 & 4.90 \\
\hline CTTNBP2 & cortactin binding protein 2 & 7.00E-04 & 4.16 \\
\hline CD1E & CD1e molecule & 6.00E-04 & 2.60 \\
\hline
\end{tabular}


medRxiv preprint doi: https://doi.org/10.1101/2020.08.05.20169136; this version posted August 6, 2020. The copyright holder for this preprint (which was not certified by peer review) is the author/funder, who has granted medRxiv a license to display the preprint in It is made available under a CC-BY-NC-ND 4.0 International license.

\begin{tabular}{|l|l|r|r|}
\hline $\begin{array}{l}\text { SH3PXD2 } \\
\text { B }\end{array}$ & SH3 and PX domains 2B & $8.00 \mathrm{E}-04$ & 2.42 \\
\hline ZNF583 & zinc finger protein 583 & $9.00 \mathrm{E}-04$ & 1.66 \\
\hline RTN1 & reticulon 1 & $6.00 \mathrm{E}-04$ & 1.60 \\
\hline AP1AR & $\begin{array}{l}\text { adaptor related protein complex 1 associated } \\
\text { regulatory protein }\end{array}$ & $7.00 \mathrm{E}-04$ & 1.54 \\
\hline EIF4B & eukaryotic translation initiation factor 4B & $7.00 \mathrm{E}-04$ & 1.53 \\
\hline RAB34* & RAB34, member RAS oncogene family & $9.00 \mathrm{E}-04$ & -1.52 \\
\hline CIB1 & calcium and integrin binding 1 & $8.00 \mathrm{E}-04$ & -1.56 \\
\hline NCAPH2 & non-SMC condensin II complex subunit H2 & $6.00 \mathrm{E}-04$ & -1.64 \\
\hline BLVRA & biliverdin reductase A & $8.00 \mathrm{E}-04$ & -1.72 \\
\hline CD82 & CD82 molecule & $7.00 \mathrm{E}-04$ & -1.73 \\
\hline IFITM2 & interferon induced transmembrane protein 2 & $8.00 \mathrm{E}-04$ & -1.75 \\
\hline ANKRD9 & ankyrin repeat domain 9 & $8.00 \mathrm{E}-04$ & -1.76 \\
\hline BCL3 & BCL3 transcription coactivator & $9.00 \mathrm{E}-04$ & -1.83 \\
\hline LGALS1 & galectin 1 & $7.00 \mathrm{E}-04$ & -1.93 \\
\hline BIN1 & bridging integrator 1 & $9.00 \mathrm{E}-04$ & -1.94 \\
\hline PTX3* & pentraxin 3 & $8.00 \mathrm{E}-04$ & -1.97 \\
\hline RNASE3 & ribonuclease A family member 3 & $8.00 \mathrm{E}-04$ & -2.23 \\
\hline ISG15 & ISG15 ubiquitin like modifier & $7.00 \mathrm{E}-04$ & -3.79 \\
\hline ATG101 & autophagy related 101 & $1.00 \mathrm{E}-03$ & -1.58 \\
\hline BHLHE40 & basic helix-loop-helix family member e40 & $1.00 \mathrm{E}-03$ & -1.74 \\
\hline SLC2A1 & solute carrier family 2 member 1 & $1.00 \mathrm{E}-03$ & -1.78 \\
\hline NECTIN2 & nectin cell adhesion molecule 2 & $1.00 \mathrm{E}-03$ & -1.80 \\
\hline SNHG15** & small nucleolar RNA host gene 15 & $1.00 \mathrm{E}-03$ & -1.91 \\
\hline ID3 & inhibitor of DNA binding 3, HLH protein & $1.00 \mathrm{E}-03$ & -2.53 \\
\hline
\end{tabular}

* Genes with two UniProt reviewed annotations: both included

** Genes with no UniProt reviewed annotation

Differential gene expression for 66 genes at $p<0.001$ in SLE-P monocytes (as in Table 3). 
medRxiv preprint doi: https://doi.org/10.1101/2020.08.05.20169136; this version posted August 6, 2020. The copyright holder for this preprint (which was not certified by peer review) is the author/funder, who has granted medRxiv a license to display the preprint in It is made available under a CC-BY-NC-ND 4.0 International license.

Table 8: Metascape analysis of enriched Reactome/KEGG/Canonical/Corum pathways in DIAMOnD-extended differential gene expression list

\begin{tabular}{|c|c|c|c|c|c|}
\hline Pathway & Pathway ID & Genes & $\begin{array}{l}\log 10 \\
\text { (p) }\end{array}$ & $\begin{array}{l}\log 10 \\
\text { (q) }\end{array}$ & ES \\
\hline $\begin{array}{l}\text { Interferon } \\
\text { gamma } \\
\text { signalling }\end{array}$ & hsa877300 & $\begin{array}{l}\text { B2M,CD44,FCGR1A,FCGR1B,GB } \\
\text { P1,GBP2,GBP3,HLA-DPA1,HLA- } \\
\text { DPB1, HLA-DQA1,HLA- } \\
\text { DQB1,HLA-DRA, HLA-DRB5,HLA- } \\
\text { E,HLA-F,HLA-G, ICAM1, } \\
\text { IRF8,IFNG,IRF1,IRF2,IRF3,IRF4,IR } \\
\text { F5,IRF6,IRF7,JAK1,CIITA,MID1,M } \\
\text { T2A,NCAM1,OAS1,OAS2,OAS3,P } \\
\text { ML,PTAFR,PTPN1,PTPN6,PTPN1 } \\
\text { 1,SP100,TRIM21,STAT1,VCAM1,T } \\
\text { RIM25,TRIM26,OASL,TRIM14,TRI } \\
\text { M10,TRIM22,IRF9,IFI30,TRIM38,T } \\
\text { RIM3,TRIM31,TRIM35,TRIM2,TRI } \\
\text { M29,TRIM17,TRIM68,TRIM62,TRI } \\
\text { M48,TRIM46,TRIM45,TRIM8,TRIM } \\
\text { 5,GBP4,GBP5,TRIM6,GBP6,GBP7, } \\
\text { ADAR,BST2,EGR1,IFI6,IFI27,IFI35 } \\
\text {,IFIT2,IFIT1,IFIT3,IFNA1,IFNA2,IF } \\
\text { NA4,IFNA6,IFNA7,IFNA8,IFNA10,I } \\
\text { FNA14,IFNA16,IFNA17,IFNA21,IF } \\
\text { NAR1,IFNAR2,IFNB1,ISG20,MX1, } \\
\text { MX2,PLCG1,EIF2AK2,PSMB8,RN } \\
\text { ASEL,SEC13,STAT2,TYK2,IFITM1, } \\
\text { ISG15,IFITM3,IFITM2,USP18,DDX } \\
\text { 58,ARIH1,SAMHD1,HERC5,IP6K2, } \\
\text { XAF1,RSAD2 }\end{array}$ & -100.0 & -96.76 & $\begin{array}{r}70 . \\
49\end{array}$ \\
\hline $\begin{array}{l}\text { Interferon } \\
\text { alpha/beta } \\
\text { signalling }\end{array}$ & hsa909733 & $\begin{array}{l}\text { ADAR,BST2,EGR1,IFI6,GBP2,HLA } \\
\text {-E,HLA-F,HLA-G,IRF8,IFI27,IFI35, } \\
\text { IFIT2,IFIT1,IFIT3,IFNA1,IFNA2,IFN } \\
\text { A4,IFNA6,IFNA7,IFNA8,IFNA10,IF } \\
\text { NA14,IFNA16,IFNA17,IFNA21,IFN } \\
\text { AR1,IFNAR2,IFNB1,IRF1,IRF2,IRF } \\
\text { 3,IRF4,IRF5,IRF6,IRF7,ISG20,JAK } \\
\text { 1,MX1,MX2,OAS1,OAS2,OAS3,PS } \\
\text { MB8,PTPN1,PTPN6,PTPN11,RNA } \\
\text { SEL,STAT1,STAT2,TYK2,IFITM1, } \\
\text { OASL,ISG15,IRF9,IFITM3,IFITM2, } \\
\text { USP18,SAMHD1,IP6K2,XAF1,RSA } \\
\text { D2 }\end{array}$ & -100.0 & -96.76 & 81.91 \\
\hline Measles & hsa05162 & $\begin{array}{l}\text { ADAR,CD3D,CD3E,CD3G,CD28,F } \\
\text { YN,IFNA1,IFNA2,IFNA4,IFNA6,IFN } \\
\text { A7,IFNA8,IFNA10,IFNA14,IFNA16,I } \\
\text { FNA17,IFNA21,IFNAR1,IFNAR2,IF } \\
\text { NB1,IFNG,IL2,IL2RA,IL2RB,IL2RG, } \\
\text { IL4,IL6,IRF3,IRF7,JAK1,JAK3,MX1, } \\
\text { OAS1,OAS2,OAS3,PIK3CA,PRKC } \\
\text { Q,EIF2AK2,STAT1,STAT2,STAT3, } \\
\text { STAT5A,TYK2,IRF9,DDX58,IFIH1, } \\
\text { CD74,HLA-DOA,HLA-DPA1,HLA- } \\
\text { DPB1,HLA-DQA1,HLA-DQB1,HLA- } \\
\text { DRA,HLA-DRB5,HLA-E,HLA- } \\
\text { F,HLA-G,IFIT1, } \\
\text { IL15,PML,PTPN11,NECTIN2,RNA } \\
\text { SEL,SP100,ICAM1,CIITA,TRIM25, } \\
\text { RSAD2,CSF2,CSF2RA,CSF2RB,G } \\
\text { RB2,IL3,IL3RA,IL4R,IL5,IL10,IL13R } \\
\text { A1,PTPN6,CD80,CD86,PTPN1,US }\end{array}$ & -56.3 & -53.20 & 31.81 \\
\hline
\end{tabular}


medRxiv preprint doi: https://doi.org/10.1101/2020.08.05.20169136; this version posted August 6, 2020. The copyright holder for this preprint (which was not certified by peer review) is the author/funder, who has granted medRxiv a license to display the preprint in perpetuity.

It is made available under a CC-BY-NC-ND 4.0 International license

\begin{tabular}{|c|c|c|c|c|c|}
\hline & & $\begin{array}{l}\text { P18,B2M,CD247,CD8A,CD8B,EGR } \\
\text { 1,LCK,LCP2,PLCG1,SH3BP2,SHC } \\
\text { 1,SYK,VAV1,ZAP70,IRF1,CTSB,G } \\
\text { BP1,GBP2,GBP3,GBP4,GBP5,GB } \\
\text { P7,CD14,FCGR1A,MRC1,SPHK1, } \\
\text { CTSK,IRF5,E2F2,FLT3,ISG15,HER } \\
\text { C5,DHX58,EIF4B,ITGA7,CD44,CS } \\
\text { K,IRF2,LYN,P2RY12,CTSC,CTSE, } \\
\text { CTSL,CTSV,CTSO,LGALS1,CTSF }\end{array}$ & & & \\
\hline $\begin{array}{l}\text { Adaptive } \\
\text { Immune } \\
\text { System }\end{array}$ & hsa1280218 & $\begin{array}{l}\text { B2M,CANX,CD3D,CD3E,CD3G,CD } \\
\text { 247,CD4,CD8A,CD8B,CD14,CD28, } \\
\text { CD80,CD86,CD74,CTSC,AP1S1,C } \\
\text { SK,CTSB,CTSE,CTSK,CTSL,CTS } \\
\text { V,CTSO,FCGR1A,FCGR1B,FYB1, } \\
\text { FYN,GRB2,HLA-DOA,HLA- } \\
\text { DPA1,HLA-DPB1,HLA-DQA1,HLA- } \\
\text { DQB1,HLA-DRA,HLA-DRB5,HLA- } \\
\text { E,HLA-F,HLA- } \\
\text { G,ICAM1,ITK,LAG3,LCK,LCP2,LY } \\
\text { N,MRC1,NFKBIE,PDCD1,PIK3CA, } \\
\text { PLCG1,PRKCQ,LGMN,PSMB8,PT } \\
\text { PN6,PTPN11,PTPRC,NECTIN2,SE } \\
\text { C13,TRIM21,SYK,VAV1,VCAM1,Z } \\
\text { AP70,ZBTB16,IFITM1,CTSF,GRAP } \\
\text { 2,SEC24C,SEC24D,SEC24B,IFI30, } \\
\text { SEC23A,SEC24A,SEC31A,PTPN2 } \\
\text { 2,CD274,SAR1B,HERC5,PAG1,PD } \\
\text { CD1LG2 }\end{array}$ & -54.45 & -51.43 & 9.63 \\
\hline $\begin{array}{l}\text { PID TCR } \\
\text { PATHWAY }\end{array}$ & M34 & $\begin{array}{l}\text { CBL,CD3D,CD3E,CD3G,CD247,C } \\
\text { D4,CD28,CD80,CD86,CSK,FYB1,F } \\
\text { YN,GRB2,HLA- } \\
\text { DRA,ITK,LCK,LCP2, } \\
\text { PLCG1,PRKCQ,PTPN6,PTPN11,P } \\
\text { TPRC,SH3BP2,SHC1,VAV1,ZAP7 } \\
\text { 0,GRAP2,GAB2,MAP4K1,PAG1,SL } \\
\text { A2,B2M,CD8A,CD8B,CSF2,IFNG,I } \\
\text { L2,IL4,IL5,IL10,NFKBIE,PDCD1,PI } \\
\text { K3CA }\end{array}$ & -43.09 & -40.33 & 43.52 \\
\hline $\begin{array}{l}\text { Th17 cell } \\
\text { differentiation }\end{array}$ & hsa04659 & $\begin{array}{l}\text { CD3D,CD3E,CD3G,CD247,CD4,H } \\
\text { LA-DOA,HLA-DPA1,HLA- } \\
\text { DPB1,HLA-DQA1,HLA-DQB1,HLA- } \\
\text { DRA,HLA- } \\
\text { DRB5,IFNG,IL2,IL2RA,IL2RB,IL2R } \\
\text { G,IL4,IL4R,IL6,IRF4,JAK1,JAK3,LC } \\
\text { K,NFKBIE,PLCG1,PRKCQ,STAT1, } \\
\text { STAT3,STAT5A,TYK2,ZAP70,IL5, } \\
\text { CD28,CD80,CD86,CSK,FYN,GRB2 } \\
\text {,LYN,PDCD1,PIK3CA,PTPN6,PTP } \\
\text { N11,VAV1,GRAP2,CD274,PDCD1 } \\
\text { LG2,CD1E,CD8A,CD8B,CD14,CD4 } \\
\text { 4,CSF2,CSF2RA,FCGR1A,FLT3,IL } \\
\text { 3,IL3RA,PTPRC,PTPN22,PAG1,FY } \\
\text { B1,ITK,LCP2,B2M,HLX,HLA- } \\
\text { E,HLA-F,HLA-G, } \\
\text { IL10,CANX,CD74,CTSB,CTSL,CIIT } \\
\text { A,LGMN,IFI30,PSMB8,E2F2,EGR1 } \\
\text {,ICAM1,IL15,SLC2A1,VCAM1,NCA } \\
\text { M1,NECTIN2,CTSK,RNASE3,PTA } \\
\text { FR,MRC1,TRIM21 }\end{array}$ & -36.81 & -34.17 & 27.71 \\
\hline $\begin{array}{l}\text { Interleukin-3, } \\
\text { Interleukin-5 } \\
\text { and GM-CSF } \\
\text { signalling }\end{array}$ & hsa512988 & $\begin{array}{l}\text { CBL,CSF2,CSF2RA,CSF2RB,FYN, } \\
\text { GRB2,IL2,IL2RA,IL2RB,IL2RG,IL3,I } \\
\text { L3RA,IL5,JAK1,JAK3,LYN,PIK3CA, } \\
\text { PTPN6,PTPN11,SHC1,STAT5A,SY }\end{array}$ & -34.26 & -31.79 & 46.33 \\
\hline
\end{tabular}


medRxiv preprint doi: https://doi.org/10.1101/2020.08.05.20169136; this version posted August 6, 2020. The copyright holder for this preprint (which was not certified by peer review) is the author/funder, who has granted medRxiv a license to display the preprint in perpetuity.

It is made available under a CC-BY-NC-ND 4.0 International license .

\begin{tabular}{|c|c|c|c|c|c|}
\hline & & $\begin{array}{l}\text { K,VAV1,GAB2,IL15,LCK,STAT1,ST } \\
\text { AT3,CANX,CD4,CD80,CD86,ICAM } \\
\text { 1,IFNG,IL4,IL4R,IL6,IL10,IL13RA1,I } \\
\text { RF4,PSMB8,PTAFR,STAT2,TYK2, } \\
\text { VCAM1,PAG1,CSK,FLT3,NCAM1, } \\
\text { MAP4K1 }\end{array}$ & & & \\
\hline $\begin{array}{l}\text { Antiviral } \\
\text { mechanism } \\
\text { by IFN- } \\
\text { stimulated } \\
\text { genes }\end{array}$ & hsa1169410 & $\begin{array}{l}\text { IFIT1,IRF3,JAK1,MX1,MX2,OAS1, } \\
\text { OAS2,OAS3,PLCG1,EIF2AK2,RNA } \\
\text { SEL,SEC13,STAT1,TRIM25,OASL, } \\
\text { ISG15,USP18,DDX58,ARIH1,HER } \\
\text { C5 }\end{array}$ & -21.23 & -19.15 & 22.88 \\
\hline
\end{tabular}

Table of pathway enrichment of differentially expressed genes in SLE-P extended using DIAMOnDalgorithm to incorporate 200 connected neighbours in protein-protein interaction network (statistical analysis as in Table 1). 
medRxiv preprint doi: https://doi.org/10.1101/2020.08.05.20169136; this version posted August 6, 2020. The copyright holder for this preprint (which was not certified by peer review) is the author/funder, who has granted medRxiv a license to display the preprint in It is made available under a CC-BY-NC-ND 4.0 International license

Table 9: EnrichR analysis of transcription factors (TFs) regulating DIAMOnD-extended differential gene expression list

\begin{tabular}{|c|c|c|c|c|c|}
\hline TF & Panel & Genes & p-value & $\begin{array}{l}\text { Adj. } p- \\
\text { value }\end{array}$ & $\begin{array}{l}\text { Combi } \\
\text { ned } \\
\text { Score }\end{array}$ \\
\hline IRF8 & ChEA & $\begin{array}{l}\text { CD274,CD74,CIITA,DDX58,MX2,S } \\
\text { TAT2,IFI35,HLA-G,USP18, } \\
\text { PSMB8, ISG20,IFIH1,HLA-DRA, } \\
\text { TRIM26, IRF5, GBP2,TRIM21, } \\
\text { IRF9 }\end{array}$ & 3.82E-14 & 3.97E-12 & 344.283 \\
\hline RUNX1 & ChEA & $\begin{array}{l}\text { SLC2A1,CSF2RB,PTPN22,ADARB } \\
\text { 1,SLA2,CD3E,SAMHD1,CD3D,CS } \\
\text { F2RA,SLC2A6,HERC5,TRIM8,LGA } \\
\text { LS1,CTSL,ATG101,SH3BP2,E2F2, } \\
\text { FFAR2,FYN,CTSE,SEC31A,STAT } \\
\text { 5A,IL10,IFNAR2,EGR1,SEC24B,S } \\
\text { TAT2,STAT3,VAV1,TRIM17,BHLH } \\
\text { E40,BCL3,CD28,ID3,GRB2,LCP2, } \\
\text { PDCD1,IRF9,LAT,LGMN }\end{array}$ & 5.85E-07 & 3.04E-05 & 33.232 \\
\hline SPI1 & ChEA & $\begin{array}{l}\text { SP100,CD82,PTAFR,CSF2RB,ICA } \\
\text { M1,TRIM8,ADORA3,TRIM25,PIM3, } \\
\text { CD14,FCGR1A,B2M,JAK1,LYN,PT } \\
\text { PN1,SYK,MX2,STAT3,PML,VAV1, } \\
\text { PSMB8,ISG20,BHLHE40,CANX,IR } \\
\text { F2,ID3,PTPN6,IRF5,LCP2,CD68,N } \\
\text { FKBIE,SEC24C,IFNAR1 }\end{array}$ & 5.04E-06 & 1.75E-04 & 28.555 \\
\hline IRF1 & ENCODE & $\begin{array}{l}\text { STAT5A,STAT1,SHC1,STAT2,MX1 } \\
\text {,IFI6,ISG15,IFI35,PSMB8,MT2A,IR } \\
\text { F2,TRIM38,B2M,TRIM21 }\end{array}$ & 1.29E-05 & 3.36E-04 & 44.886 \\
\hline RELA & ENCODE & $\begin{array}{l}\text { CD74,CIITA,STAT1,TYK2,IL2RG,P } \\
\text { SMB8,ICAM1,BST2,IFIH1,IRF1,BH } \\
\text { LHE40,IRF2,IGFLR1,NFKBIE,B2M, } \\
\text { JAK3,HLA-DQA1 }\end{array}$ & 2.93E-04 & 6.09E-03 & 21.405 \\
\hline STAT3 & ENCODE & $\begin{array}{l}\text { EGR1,RNASEL,WBP1,STAT1,SH } \\
\text { C1,STAT2,STAT3,PDCD1LG2,PS } \\
\text { MB8,HLA-E,ICAM1,HERC5,BST2, } \\
\text { ISG20,MT2A,IRF1,BHLHE40,IRF2, } \\
\text { IRF9 }\end{array}$ & 4.13E-03 & 7.16E-02 & 10.776 \\
\hline TP63 & ChEA & $\begin{array}{l}\text { CD82,PTAFR,ADARB1,SLA2,TRIM } \\
\text { 29,CTSK,GRAP2,SH3PXD2B,PLC } \\
\text { G1,IFNAR2,EGR1,IL4R,SYK,STAT } \\
\text { 1,GAB2,PDCD1LG2,ALOX15B,PM } \\
\text { L,TPST1,ZAP70,IFNG,OAS2,IRF1, } \\
\text { OAS3,IL2RB,PRKCQ,GRB2,IRF5,I } \\
\text { RF6,CD44 }\end{array}$ & 6.98E-03 & 1.04E-01 & 7.975 \\
\hline
\end{tabular}

Table of transcription factors and consensus target genes using ENCODE and ChEA of differentially expressed genes in SLE-P extended using DIAMOnD-algorithm to incorporate 200 neighbours in protein-protein interaction network (Terminology and analysis as in Table 2). 
medRxiv preprint doi: https://doi.org/10.1101/2020.08.05.20169136; this version posted August 6, 2020. The copyright holder for this preprint (which was not certified by peer review) is the author/funder, who has granted medRxiv a license to display the preprint in It is made available under a CC-BY-NC-ND 4.0 International license. 